\begin{tabular}{lcc}
\hline Mezhep Arassttrmaları Dergisi & 14, sy. 1 & (Bahar 2021): 42-94 \\
\hline Journal of Islamic Sects Research & 14, no. 1 & (Spring 2021) : 42-94 \\
\hline Hakemli Arastırma Makalesi | Peer-reviewed Research Article
\end{tabular}

( Peer-reviewed Research Article

\title{
ELDİVAN'DAN “İLMİN EFELİĞİNE” BİR ÖMÜR: PROF. DR. HASAN ONAT
}

\author{
A Life Span from Eldivan to "The Bravery of Science": Prof. Hasan \\ Onat
}

Sönmez KUTLU1 1

\begin{abstract}
Öz
Hasan Onat, Çankırı'nın Eldivan ilçesinde doğdu. İlköğretimini Eldivan Merkez İlkokulu'nda, liseyi yatılı olarak Yozgat Lisesi'nde bitirdi. 1974 yılında Ankara Üniversitesi İlahiyat Fakültesi'ne kayıt yaptırdı. Lise eğitiminden itibaren çok okuma, araştırma ve sorgulama alışkanlığı edindi; şiir ve öykü yazmaya başladı. İlahiyattaki başarıları, tecessüs ruhluluğu ve ilmî merakı Prof. Dr. E. Ruhi Fığlalı'nın dikkatini çekti ve onu Mezhepler Tarihi alanında doktoraya davet etti. Böylece Mezhepler Tarihi'nde araştırma görevlisi oldu. Doktorasın başarıyla bitirdikten sonra yardımc1 doçentlik kadrosuna atandi. Doçentlik ve profesörlük kadrolarında görev yaptı. Yaklaşık kırk yıl fakültesinde alanında dersler verdi. Elliyi aşkın yüksek lisans ve doktora tezine danışmanlık yaptı. Maturidi-Yesevi Otağı Derneği tarafindan 2 Eylül 2015 Safranbolu'da “İlmin Efesi Ödülü” ile ödüllendirildi. Kavramlar ve metaforlarla düşündü ve düşündürdü. Yıllarca sürdürdüğü radyo ve televizyon yapımcılığı ve sunuculuğu yapt1. İslam Mezhepleri Tarihi'nde kendinden öncekilerin fikir ve usulünü daha ileriye taşıması bakımından yeni
\end{abstract}

\begin{abstract}
Hasan Onat was born in the Eldivan district of Çankırı. He completed his primary education at Eldivan Center Primary School and at Yozgat High School as a boarding student. He enrolled in Theology Faculty of Ankara in 1974. He acquired the habit of reading, researching and questioning a lot since his high school education; He began to write poetry and short stories. Prof. E. Ruhi Fığlalı invited him to do a PhD in the History of Sects. He became a Research Assistant in Theology. After successfully completing his doctorate, he was appointed to the staff of Assistant Professor. $\mathrm{He}$ worked as an Associate Professor and Professor. He gave lectures in his field for about forty years. He has supervised more than fifty master's and doctoral theses. He was awarded with "the Bravery of Science Award" in a ceremony held in Safranbolu on 31 August 2015-12 September 2015 by the MaturidiYesevi Otağı. He thought and made thought through concepts and metaphors. For years, he
\end{abstract}

1 Prof. Dr. Ankara Üniversitesi İlahiyat Fakültesi, İslam Mezhepleri Tarihi Öğretim Üyesi, Ankara, Türkiye/ e-mail: skutlu@divinity.ankara.edu.tr /ORCID ID: https://orcid.org/0000-0002-2257-5329.

\begin{tabular}{ccc}
\hline Başvuru|Submission & Kabul|Accept & Yayın|Publish \\
13.06 .2021 & 20.06 .2021 & 30.06 .2021 \\
\hline DOI: $\quad 10.18403$ /emakalat.951961
\end{tabular}


bir çığır açtı. Alanında pek çok araştırma ve çeviri gerçekleştirdi. Din Kültürü ve Ahlak Bilgisi ders programlarının hazırlanmasında; İlahiyat programlarının yenilenmesinde önemli rol oynadı. Hasan Onat, "Kök Bilim Paradigması" adiyla İslam bilimlerinde yeni bir bilim paradigmas1 ile "yeni bir İslam medeniyeti" tezini sistemleştirmek için çalıştı. Hasan Onat, Covid-19 illetine yakaland1 ve 26.09.2020 tarihinde hayata veda etti.

Anahtar Kelimeler: Hasan Onat, Mezhepler Tarihi, İslam Ortak Paydas1, Yeni Bir İslam Medeniyeti, Kök Bilim Paradigmas1 established a throne in the hearts of his audience via his radio and television broadcasting. In the History of Islamic Sects, he carried the ideas and methods of his predecessors forward and opened a new era in his field. He played an important role in the preparation of the Religious Culture and Moral Knowledge curriculum and in the renewal of theology programs. Hasan Onat, worked to systematize a new scientific paradigm in Islamic sciences under the name of "Root Science Paradigm" and the thesis of "a new Islamic civilization" Hasan Onat, who devoted his life to science, was just beginning to reap the fruits of his work, but he caught the Covid19 disease and died on 26.09.2020.

Key words: Hasan Onat, History of Islamic Sects, Common denominator of Islam, A new civilization of Islam, Root science paradigm

\section{GİRIŞ}

Ankara Üniversitesi İlahiyat Fakültesi İslam Mezhepleri Tarihi Anabilim Dalı öğretim üyesi Prof. Dr. Hasan Onat; fikrî, edebî ve ilmî kişiliği ile tanınan çok yönlü bir bilim insanıdır. Hayatını bilime, araştırmaya, öğrenci yetiştirmeye adadı ve çok sayıda araştırma yaptı. İnsaniliği, nezaketi, vakarı, ahlakı ve cesareti ile her çevreden insanın kalbinde yer edindi. Sadece İslam Mezhepler Tarihi ve Çağdaş İslam Akımları alanlarıyla yetinmedi, yanı sıra Sosyal Bilimler, Felsefe, Sosyoloji, Psikoloji, Sosyal Psikoloji ve Antropoloji alanlarında da önemli bir birikime sahipti. Önemli fikirlere ve tezlere sahip olan Hasan Onat'n biyografisini yazmak zor olmakla beraber ilk doktora öğrencisi ve 1988 yılından itibaren aynı kürsüde beraber çalışmış birisi olarak, onun biyografisini bir makale çerçevesinde genel hatlarıyla ve kronolojik olarak yazmaya çalışacağım. 
Hasan Onat'in analiz edilmesi gereken pek çok görüşü bulunmaktadır. Ancak böyle bir makale çerçevesinde bunların tamamını ele almak mümkün değildir. Özellikle onun İslam Mezhepleri Tarihi, bilim ve bilimsel yöntem, İslam'ın kök değerleri, Alevilik-Bektaşilik, Şiilik, çağdaş İslam akımları, Türkiye'nin gündemindeki din-siyaset ilişkisi, cemaat ve tarikatlar, demokrasi, laiklik, şiddet ve terör, kadın sorunu, din eğitim ve öğretimi gibi konulara dair pek çok makale yazdı ve önemli katkılar sundu. Bunların her birisi ayrı bir araştırmanın konusu olduğundan onun biyografisini ele aldığımız bu makalede görüşlerinin analizine girilmeyecektir.

Makale'de kaynak olarak Hasan Onat'in kendi arşivi2, kitapları, makaleleri, konuşmaları ve medya paylaşımları ile kendisinin Yozgat Lisesi'nde bulunan öğrenci dosyası, Ankara Üniversitesi İlahiyat Fakültesi'nde mahfuz özlük dosyası, yanı sıra şahsi tanıklıklarım, Hocası Prof. Dr. Ethem Ruhi Fığlalı'nın onun hakkındaki söyleșisi, eşi Nurten Onat'ın söyleşisi, dostları ve öğrencilerinin vefatından sonra onun hakkında yazdığı makaleleri ve anlatıları, diğer görsel ve yazılı medya dokümanları kullanılmıştır. ${ }^{3}$

\section{Hasan Onat'ın Ailesi, İlk, Orta ve Lise Eğitimi}

Hasan Onat, 01.01.1957 yılında Çankırı'nın, yâren geleneği ve kirazı ile meşhur Eldivan ilçesinde çiftçilik ve hayvancılıkla geçimini sağlayan bir ailede dünyaya geldi. Annesi Hafize Onat ve babas1 Mustafa Onat'tır. Savaş isminde bir kardeşi vardır.

Yozgat Lisesi arşivinde bulunan 728 numaralı dosyada yer alan bilgilere göre, Hasan Onat, 1967 yılında Eldivan Merkez İlkokulu'ndan başarılı bir öğrenci olarak mezun oldu. 1968-1969 eğitim öğretim yılında Eldivan Dümel-Saray Ortaokulu 1-A şubesine 26 nolu öğrencisi olarak kayıt yaptırdı. 1. sınıfı iyi derece ile geçti. İlkokul öğretmeni Mehmet Kara'nın teşvikleriyle 1969-1970 eğitimöğretim yılında kaydını Yozgat Merkez Ortaokulu 2-B şubesine aldırdı. Başarıları dolayısıyla Yozgat Merkez Ortaokulu müdürü tarafından 1. kanaat döneminde "okul içi ve dışındaki davranışları, gayret ve başarıları dolayısıyla üstünlük gösterdiğinden takdire layık" görüldü ve babası da tebrik edildi. 1971 yılında Ortaokulu bitirdikten sonra Yozgat Lisesi 4/FEN-A sınıfına 189 nolu öğrenci olarak

\footnotetext{
2 Hasan Onat Arşivini kullanmamıza izin veren Nurten Onat Hanımefendi’ye, Oğuz Onat ve Yavuz Onat'a çok teşekkür ediyoruz.

${ }^{3}$ Makalenin yayınlanma aşamasına kadar emeği geçen başta Prof. Dr. Ethem Ruhi Fığlalı, Doç. Dr. Mehmet Kalaycı, Doç. Dr. Rıfat Türkel ve diğer meslektaşlarıma teşekkürü bir borç biliriz.
} 
kaydoldu. 1973-1974 eğitim-öğretim yılında Yozgat Lisesi 6/FEN-A sınıfındaki başarısı dolayısıyla Lise Müdürlüğünce not ortalaması 7.1 tutturduğundan Disiplin Yönetmeliğinin 31. maddesinin A ve B fikralarına göre TEŞEKKÜRNAME ile taltif edildi. Hasan Onat, anılarında da yazdığı gibi, lise sürecinde başarılı bir öğrenci idi. Bütün hocaları tarafından seviliyor ve başkalarına örnek gösteriliyordu. En başarılı olduğu dersler; fizik, kimya ve matematik idi. Onat, 01.07.1974 yılında Yozgat Lisesi Parasız Yatılı Okulu'ndan mezun oldu. Öğrenciliği dönemindeki dosyası, 728 numaralı Hasan Onat dosyası olarak Yozgat Lisesi arşivinde saklanmaktadır. ${ }^{4}$

Hasan Onat, 1969 y1lında 12 yaşında Eldivan'da ailesinden ayrıldı; diğer yatılı ögrenciler gibi, sadece yaz ve Şubat tatillerinde ailesinin yanına gidebildi. Yaz tatillerinde ailesinin işlerine yardımcı olmayı sürdürdü. Duygusal bir kişiliğe sahipti. Anne ve babasını çok seven ve hürmet eden bir evlatt1. Kendisini okuyarak ve yazarak geliştirdi. Eşi Nurten Hanım, kendisiyle yapılan bir söyleşide bu durumu şu şekilde açıklamaktadır:

"Hasan Onat, anne babasına son derece bağlı, elinden geldiğince yardım etmeye çalışan iyi bir evlattı. Kendine göre ilkeleri olan biriydi. Çok duygusal bir insan olmasına rağmen, duygusal yönünü fazla öne çıkarmazdı. Ama aslında duygusal bir insand1. Ben annesine "anne" dediğini hiç duymadım. Hep "ana" ya da "anam" derdi."

Hasan Onat'ın, lise sürecinden itibaren yenilikleri ve teknolojik gelişmeleri takip eden birisi olduğu anlaşılmaktadır. Çünkü lise son sınıfta babasından üç şey istedi: fotoğraf makinası, ses kayıt cihaz1 ve daktilo. Babas1, onun bu isteklerini yerine getirdi. Çok sevdiği babasını, 1998 yılında erken kaybetti. Babası da onu çok seviyor ve onun başarılarıyla gurur duyuyordu.

Hasan Onat, İlahiyata başladığı y1l yazdığ1 anılarında ${ }^{6}$ dönemin ideolojik atmosferinden etkilendiğini ve inançla ilgili bunalımlı dönemler geçirdiğini, ancak bunlardan din dersi hocasının yardımıyla; okuyarak ve araştırarak kurtulduğunu şöyle anlatmaktadir:

"Zannediyorum lise birinci sınıfta idim. İlk defa o zaman, içimi gizli gizli kemiren şüphe tohumları su yüzüne çıkmıştı. Arkadaşlarla tartışmalarımızda, ateşli ateşli Allah'ın varlığını savunurken, nasıl

\footnotetext{
$4 \mathrm{Bu}$ dosyanın incelenmesine müsaade eden Yozgat Lisesi yetkililerine ve bu konuda aracılik yapan Prof. Dr. Mehmet Atalan'a teşekkür ediyorum.

5 Nuran Üçok, "Nurten Onat Hanımefendi İle Eşi Hasan Onat Üzerine Söyleşi”, Türk Yurdu 399 (Kasim 2020), 105.

6 Hasan Onat, "Bir Üniversiteli Gencin Hatıra Defterinden Seçmeler", Tarihsiz. (1974-1975 Ögretim yılı Bahar dönemi olabilir.), 7.
} 
oldu bilemiyorum, ben de yavaş yavaş inançsızlık uçurumuna doğru yuvarlanmağa başlamıştım. Hiç unutmam, bir gün namaz kılmak için abdest aldım; tam namaza başlamak üzereydim ki, içimdeki isyan birden bire alevlendi: Eğer Allah yoksa ben niçin namaz kılıyorum diye seccadenin başında uzun süre beklemek zorunda kaldım. Kararsızlık dönemim aylarca sürdü. Şüphelerimi gizleyerek konuyu sınıfta Din dersleri hocasına açtım. Allah razı olsun hocamın verdiği cevaplar ve o esnada bulabildiğim kadarıyla okuduğum kitaplar, beni yeniden imâna kavuşturmuştu."

\section{Hasan Onat'ın Edebî Yönü}

Hasan Onat, Yozgat Lisesi'nde iken sadece derslerle ilgilenmedi; çeşitli alanlarda çok sayıda kitap okudu. Kitap okuma alışkanlığı sayesinde okuma, yazma ve konuşma melekelerini geliştirmeye çalıştı. O, bu dönemde şiire merak sardı ve çeşitli konularda şiirler yazd1. Aslında o, köyünde iken iç içe yaşadığı tabiatı, dünyayı ve evreni hep merak etti. Bu konuda hep arasstırma ve gözlemlerde bulundu. Tabiatı anlamadan insanı anlamanın mümkün olmadığ 1 sonucuna ta o zaman varmıştı. İlahiyat eğitimine başladığı yılın ikinci döneminde köyünde bir hafta kalıp döndükten sonra, 15 Nisan 1975 tarihinde kaleme aldığı anısında ${ }^{7}$ kendisinin tabiatla iç çeliğini şu şekilde dile getirdi:

"Geçen hafta köye gitmiştim. Mis gibi kokan, hayat fışkıran toprağı, ilk defa tanıyormuşçasına doyasıya avuçladım. Sırtüstü uzandım iyice kabarmış toprağa, gözlerimle gökyüzünün dibini bulmaya çalıştım. Şimdi üzerindeyim; yarın öldüğüm zaman beni kucağına alacak, müşfik bir anne gibi bağrına basacak bu toprağı iyi tanımak lazım. Ne kadar da yakın hissediyorum kendimi toprağa. İnsanın topraktan yaratıldığını söylüyorlardı, galiba doğru. Toprağ tanımayan insanı nasil tanır? ...

Toprakla oynarken yeni çatlamıș bir tohum geçti elime. Bir elma çekirdeği olduğunu anlamakta gecikmedim. Baktım, baktım. Emin olun ilk defa zihnimin çatlarcasına zorlandığını hissettim. Biraz ötemde tomurcukları patlamaya yüz tutmuş koca elma ağac1, avucumda yeni çatlamış elma çekirdeği ... Tepemde dolaşan yağmur yüklü bulutlar, uzaklardan uğultusu kulaklarıma kadar ulaşan dere, şırıl şırıl şarkı söyleyen çeşme... Sicaklığı iliklerime kadar ulaşan güneş, bu zamana kadar hiç böylesine 1sıtmamıştı beni. Tatlı tatlı esen rüzgar, hiç böylesine güzel kokular getirmemişti bana. Ya

\footnotetext{
7 Hasan Onat, "Bir Üniversiteli Gencin Hatıra Defterinden Seçmeler", 15 Nisan $1975,5-6$.
} 
kuşlar, onların da böylesine güzel, içten öttüğünü ilk defa fark ediyorum."

Hasan Onat'n bir kitap olarak algıladığı tabiatı ve edebî eserleri okuma tutkusu, edebiyata ve şiire gönül vermesine sebep oldu. İlk şiir denemelerinden birisinin lise yllarında Eldivan'da sabahtan akşama kadar kiraz topladığ günlerin anısına kirazla ilgili yazdığ1 Nurten Hanım'in söyleşisinde yer verdiği şu cümleden anlaş1labilmektedir:

"Bir şiir de kiraza yazdım derdi ve birkaç mısrasını da okurdu. Ancak şu an bu şiir nerededir bilmiyorum."

Hasan Onat'ın şairliğinin tabiatla sınırlı kalmadığı, yanı sıra sevgi ve insani değerler üzerine de şiirler yazdığı çevresi tarafından bilinmektedir. Beş yıllık İlahiyat eğitimi sırasında da şiir yazdı; fakat akademisyenliğinin ilk dönemlerinde şiir yazmayı sürdürüp sürdürmediği tam olarak tespit edilememektedir. Kendisini tanıdığımız 1987 yılından sonraki süreçte eskiden şiir yazdığını ve bazı şiirlerinin yayınlandığını söylerdi, ancak yeni şiirler yazdığından bahsetmezdi. Abdülkadir Tellioğlu'nun Ankara Üniversitesi İlahiyat Fakültesi 1978-1979 Mezunları Yı1lığı'nda Hasan Onat için "Şiir ve Öykü çalışmaları vardır." ifadesi onun "şiir" yanı sıra "öykü" çalışmalarının olduğunu ortaya koymaktadır. Halen müphemliğini koruyan bu iki hususun müstakil çalışmalarla ortaya çıkarılacağını ümit ediyoruz.

Hasan Onat, şiir okumayı da sever ve çok güzel şiir okurdu. Zaman zaman Mehmet Akif'in Çanakkale, Necip Fazıl Kısakürek’in Sakarya ve Fahri Erdinç'in Taş adlı şiirlerini okurdu. Özellikle Taş adlı şiir, meslektaşlarıyla yaptığı edebi sohbetlerde ve seyahatlerde kendisinden okunması istenen şiirlerin başında gelirdi. $\mathrm{Bu}$ şiir Hasan Onat'in ismiyle anılır olmuş ve seslendirdiği bazı kayıtlar YouTube'dan dinlenilir olmuştu. Necip Fazll'in şiirlerini ve edebiyatını çok beğenirdi. Onun kelimelerle oynadığını söylerdi, ancak "Üstad Necip Fazıl'dan din öğrenilmez; edebiyat ve şiir öğrenilir." derdi.

Hasan Onat, ilk şiirlerinden birisini "Son Soluk" adiyla kaleme aldı. Bu şiirin Hisar Dergisi’nde yayınlandığını biliyoruz. Ancak yayınlanmamış şiirlerinin de bir gün özel arşivinden bulunup

\footnotetext{
${ }^{8}$ Hasan Onat'in bu şiirinin tamamına ulaşamadık. Ancak, kardeşi Savaş Onat "Şisti ayaklarım kiraz elinden" adlı bu şiirin birkaç mısrasını ezberinden bize şöyle aktardı: "Topladım topladım da sepetim dolmadı / Bekledim bekledim de akşam olmadı / Şisti ayaklarım kiraz elinden"
} 
yayınlanacağına inanıyoruz. ${ }^{9}$ İlk yayınlanan şiiri olduğunu sandığımız bu şiire burada yer vermek istiyoruz:

Son Soluk

Merdivenlerde ayak sesi; gicırdiyor,

Yillar yılı aşınan o çürük tahtalar.

Rüzgâr hangi delikten içeri giriyor;

Esiyor, üşütüyor. Oynuyor duvarlar.

Son defa sallaniyor dalda sari yaprak

Düşüyor kucağına bu kara topră̆ın

Haykırıyor bir yıldız beynime çarparak,

Meusim sonbahar, uyan, bozulacak bağın?

Eğri yolun göründü ufukta bir sonu

Gökte devam edecek galiba yolculuk

Sonsuzluk evet; yokluk anlat bana onu

Hangi kilometrede bitecek son soluk. ${ }^{10}$

Hasan Onat'in dinî-felsefì şiirler yazdığı, sınıf arkadaşı Abdülkadir Tellioğlu tarafından belirtilmektedir. Tellioğlu onun bu tür bir şiirinden iki mısrayı hafızasından şu şekilde bize yazdırdı:

Başı dönmüş atom her an Allah'1 anar

İnanmış bir kalp Allah der içten yanar ${ }^{11}$

Hasan Onat'in gençlik yıllarında yazdığı şiirlerden birisinin de sevgi üzerine olduğu anlaşılmaktadır. Bu şiirin bir kısmı, fakültemiz Türk Din Musikisi Anabilim Dalı hocalarından Prof. Dr. Bayram Akdoğan tarafından bestelendi. Akdoğan, Onat'ın kendisine elle yazılmış bazı şiirlerini verdiğini, bunların arasından birisinden bir bölümü seçip bestelediğini, bu metinleri daha sonra hocaya geri verdiğini söylemektedir. Maalesef onun geri verdiği şiirlerin kayıtlarına ulaşamadık. Bestelenen ve notalandırılmış olarak yayınlan ilgili şiirin bir kıtası şöyledir:

\footnotetext{
${ }^{9}$ Doğduğu evdeki kitaplığında birkaç şiirine bu makalenin yazımından sonra ulaştık. Bazılarını ekler (Dosyalar) bölümünde yayınladık.

10 Hasan Onat, "Son Soluk", Hisar Aylık Fikir ve Sanat Dergisi 169 (Ocak 1978), 27.

11 Abdülkadir Selvioğlu'nun Hasan Onat ile ilgili gönderdiği not. Kendisine teşekkür ediyoruz.
} 
Gel sevgilim haydi gel, otur şu başucuma;

Saçların yumak yapsin, dürsün karanlıkları.

Ellerin doldursun yıldizlari avcuma,

Birlikte saralım o esrarl ufuklar.

"12

\section{Hedefleri Olan Başarılı Bir İlahiyat Öğrencisi}

Hasan Onat, 1974 yılının güz döneminde Ankara Üniversitesi İlahiyat Fakültesi'ne kaydını yaptırdı. Aslında İlahiyat okumak gibi bir fikri yoktu, çünkü onun istediği, fen bilimleriyle alakalı bir fakülte okumaktı. Onun İlahiyat'ı kazanması, bașta babasını, sonra Lise'den bazı öğretmenlerini de şaşırtmıştı. Babası, onun İlâhiyat Fakültesi'ni kazandığını duyunca, epeyce sinirlendi. Ankara İlahiyat Fakültesi'ndeki ilk günlerinde, kendi kendisini tanımak ve geliştirmek için "Hiç olmazsa kendi fikrî gelişmemin içinden geçtiği çizgileri, yükseliş ve düşüşleri; sıkıntılarımı, sevinçlerimi unutulmak denen tehlikeden bir dereceye kadar korur." diyerek babasının aldığ daktilo ile günlük tutmaya başlad1. "Bir Üniversiteli Gencin Hatıra Defterinden Seçmeler" adıyla 7 Kasım 1974 tarihinde yazılmış 6 sayfalık ilk günlükte, öğrencisi olmayı aklından geçirmediği İlahiyat Fakültesi'ne kayıt yaptırdıktan sonra Fakülte ile ilgili ilk gözlemlerini şu şekilde dile getirdi:

"On sekiz yaşıma girmek üzereyim. .... Kader rüzgârı öyle bir fırlattı ki, İlâhiyat Fakültesi gibi aklımın köşesinden geçmeyen bir okul çıktı karşıma. Gerçi az çok dindar sayılacak bir gencim; zaman zaman aksatsam da namazımı kılarım; Kur'an okumasını bilirim. Bütün bunlara rağmen, bu okula nasıl 1sınacağımı düşünüyorum; çünkü benim bütün istediğim, fen bilimleriyle alakalı bir okuldu. İlâhiyat Fakültesi'ni kazandığımı duyunca, babamın nasıl sinirlendiğini hiç unutamam. Oysa namazlı abdestli temiz bir Müslüman... Artık Fakültemin adı "İlâhiyat" da olsa, ben de bir üniversiteliyim. Üç gündür okula gidip geliyorum. Değişik bir çevre, yeni arkadaşlar, bu zamana kadar adını bile duymadığım dersler."

Ankara'da karşılaştığ1 Lise'den İngilizce hocasına İlahiyat Fakültesi'ne kayıt yaptırdığını söylediğinde, hocası memnuniyetsizliğini bildirmiş ve ona kızmıştı. İlahiyatı kazandığını sonradan öğrenen Tarih hocası ise çok sevinmiş ve fakültesini değiştirmemesi için ona "Söyleyin o deli oğlana, sakın o okulu değiştirmesin, o sahada çok büyük boşluk var." şeklinde özel haber

\footnotetext{
12 Bayram Akdoğan, "Prof. Dr. Hasan Onat Hoca'mın Bir Güftesini Bestelememle İlgili Bir Hatıram”, Türk Yurdu 399 (Kasım 2020), 110-111.
} 
yollamıştı. Bu konudaki tepkileri kendi kaleminden dökülen şekliyle okuyalım:

"Geçenlerde lisedeki İngilizce hocamla karşılaştım. Hayatımda bu kadar küçüldüğümü hatırlamıyorum. Yer delinse, dibine girmek isterdim. İlâhiyat Fakültesi adını duyunca, o kadar sinirlendi ki, kıpkırmızı oldu ve hiç unutmayacağım şu sözleri söyledi: "Yazık. Çürüyüp gideceksin. Biz senden neler bekliyorduk." İster istemez ağzımdan şu sözler döküldü: "Hocam değiştireceğim bu okulu, zaten bir türlü ısınamadım." Çevremdeki herkes, babam dahil, bu okula girdim diye, bana kırgın, memnun değiller. Sâdece lisedeki Tarih Hocam Muallâ Hanım, benim İlâhiyat'ı kazandığımı duyunca, "Söyleyin o deli oğlana, sakın o okulu değiştirmesin, o sahada çok büyük boşluk var." diye haber göndermiş. Bilemiyorum. Bilemiyorum. Bilemiyorum. Bu cemiyette din anlayış1 nasıl, acaba beni tenkid edenler doğru mu düşünüyorlar?”13

Yazdıkları anılardan Hasan Onat'in büyük hedefleri olan mefkure sahibi bir öğrenci olduğu açıkça anlaşılmaktadır. O, İlahiyat’a geldiği ilk günden itibaren Lise'de kazandığı tecessüs ruhluluğu, merak ve araștırma yeteneğini hiç kaybetmedi; Ankara İlahiyat'in ilmî muhitinde bu özelliklerini daha da geliştirdi. Fakülteye ilk girdiği derslerde profesörlerin nasıl insanlar olduklarını merak etti ve onları görmek için sabırsızlıkla bekledi. Onun kafasında canlandırdığ profesör, "koca kafalı, saçları dökülmüş, her şeyi bilen, bakışlarıyla insanın içini okuyan, tek kelimeyle mükemmel bir insan" idi. Daha önce ulaşılmaz unvanlar ve makamlar olarak gördüğü profesörlüğün hiç de öyle olmadığını dile getirdi, muhtemelen kendisinin bir profesör olabileceğini o gün kafasına koydu. $\mathrm{Bu}$ konudaki kanaatlerini eleştirel bir şekilde satırlara şöyle yazdı:

"Profesörler de bizim gibi, daha doğrusu bizden pek farkı olmayan insanlarmış. Kafamdaki Prof. heykelinin yıkılması hiç de hoşuma gitmedi. Böyle devam ederse, daha pek çok şeyin yıkıldığını, eriyip gittiğini göreceğiz galiba. Kendimin hayalperest bir insan olup olmadığımı düşünüyorum. Belki de idealistliğimden kaynaklanan bir durumla karşı karşıyayım. Her ne olursa olsun, insanın kafasında geliştirdiği, yücelttiği, varlığının bir parçası haline getirdiği, bazı mefhumların hiçbir değer taşımadığını veya o kadar fazla değere sahip olmadıklarını anlaması gerçekten oldukça acı bir şey.”

Hasan Onat, lise yıllarında edindiği okuma alışkanlığını İlahiyat eğitimi boyunca da sürdürdü. Onun yastığının altında, masasında, koltuğunda ve çantasında her daim kitap oldu. Onun ilk okuduğu kitaplardan birisinin İsmail Hâmi Danişmend'in İslam Medeniyeti

\footnotetext{
${ }^{13}$ Hasan Onat, "Bir Üniversiteli Gencin Hatıra Defterinden Seçmeler”, tarihsiz, 7.
} 
olduğu anlaşılmaktadır. Onat'in kitabı okuduktan sonra onun şu sözlerinden çok etkilendiği görülmektedir:

"Eğer bu günkü Garp medeniyetinden İslâm ilimleri (İslam Medeniyeti, s.1) kaldırılacak olursa, atom sanayîi derhal durur, tayyâreler yola düsser, fabrikalar işlemez olur, bankalar derhal kapanır ve hastahaneler mezarlık haline gelir."

$\mathrm{Bu}$ cümleler Onat'ı Müslümanların bugünkü durumuyla geçmiştekini kıyaslamaya sevk etti. İslam dünyasının durumuyla o günden itibaren ilgilendiği ve karşı karşıya bulunduğu sorunlardan nasıl çıkılacağına dair çözümler aradığı anlaşılmaktadır. İsmail Hâmi Danissmend'in İslam Medeniyeti adlı eserindeki bilgiler, kendisine Lise yıllarında Tarih dersinde Rönesans ve Reform ile ilgili üniteleri okuduktan sonra ilgili ders kitabının üzerine düştüğü notu hatırlattı ve İslam dünyasının da böyle bir rönesansa ihtiyaç duyduğunu şu şekilde dile getirdi:

"Bu ifâdeler bana, Batılı E. M. C. Bodley'in bir itirafını hatırlattı: "Biz rönesansı İslâmiyete borçluyuz." Bunun gibi fikirler, şüphesiz, gururumu okşuyor ve hoşuma gidiyor; fakat henüz "medeniyet"in ne olduğunu bilmediğim gibi, Rönesans hakkında da tarih kitabında yazılandan başka bir şey bilmiyorum. Lise son sınıfta, tarih dersinde Rönesasn ve Reform bahsini okuduktan sonra içimden geçenleri kitabın üzerine şöyle yazmıştım: "Karakteri farklı olsa bile, bugün İslâm dünyasında da bir rönesans ve reform kaçınılmaz tek yol gibi görünmektedir."14

Hasan Onat, İlahiyat eğitiminin ikinci haftasında Fakülte profesörlerinden birisinin vefatından çok etkilenerek hayat ve ölüm olgusuna anlamaya çalıştı. Hacı Bayram Camii'nde kılınan cenaze namazına katıldı, sonra bir köşeye dikilip cenazelerin omuzlarda götürülmesini izledi. Bu sırada Yahya Kemal'in Sessiz Gemi şiirini sessizce içinden okudu. Muhtemelen ileride almayı hedeflediği bir unvanı temsil eden bir profesörün bayrağa sarılı tabutunun, "hem oldukça kalabalık hem de genç genç insanlar" tarafından taşınmasını görünce çok etkilendi. Bir taraftan bu tabloya hayran olurken diğer taraftan ölümün soğukluğunu düşünerek "hayat"1 ve "ölüm”ü sorgulamaya başladı. Eğer Hasan Onat ülkemizde veya batıda felsefe okumuş olsaydı, şimdi felsefe dünyasında onun fikirleri tartışıliyor olabilirdi. O, hayat ve ölümle ilgili düşünceleri ve sorgulamalarının bir kısmını şu şekilde satırlara döktü:

"Bir hoca için son saadet öğrencilerinin elleri üzerinde öbür aleme yollanmak mi acaba?

${ }^{14}$ Hasan Onat, "Bir Üniversiteli Gencin Hatıra Defterinden Seçmeler", 16 Kasım $1974,1-2$. 
"Ölüm", gerçekten çok soğuk ve korkunç bir şey ....,

"Hayat" denilen şeye yeni bir anlam bulmam gerekiyor. Hoş bu zamana kadar doğru dürüst, hayatın bir anlamın olup olmadığını düşünmüş değilim ya... Şimdiye kadar düşünmemiş olmam, bundan sonra da düşünmememi gerektirmeyeceğine göre, düşünmek zorundayım. Öyleyse önce "düşünme"den işe başlamak lazım." 15

Hasan Onat, her ne kadar ilk dönemlerde, İlahiyat yıllarında derslerde, "Ben bir köylü çocuğuyum. Ellerimin nasırları, bazan düzenli not tutmamı bile engelliyor." dese de, düzenli not tutan ve okuduğu eserlerden önemli yerleri kaydeden bir öğrenci idi. Onun okuduğu eserlerden not alma alışkanlığı, akademisyen olduktan sonra bilimsel bir formata girdi ve aldığ notları toplumsal duyarlılık bilinci ile makalelerinde okurları ile paylasst1. Hatta onun daha sonra yazmaya devam ettiği günlükleri neredeyse "kitap okuma günlükleri" haline geldi. Bu günlüklerden onun hangi tarihte hangi kitaplar1 okuduğunu ve ne tür notlar aldığını görebilmek mümkündür. Hasan Onat, bu notlarını 1988 yılından itibaren hazırlayıp sunduğu radyo programlarında, yazılarında ve konuşmalarında da paylaşmaya devam edecektir.

Hasan Onat, İlahiyat 1. sınıfın 2. yarısında tıpkı lise yıllarındaki gibi bazı fikrî buhranlar ve istihaleler yaşadı. Ancak onun "dünyasını karartan bu korkunç bunalımdan" yine okuyarak, sorgulayarak ve eleştirerek kurtulduğu anlaşılmaktadır. $O$, bu günlerini günlüğünde ${ }^{16}$ şu şekilde dile getirmektedir:

"Günlerdir dünyayı karartan korkunç bunalımın sisleri yavaş yavaş dağılır gibi olmaya başladı. Bir iki gündür biraz daha rahat uyuyabiliyorum. Sanki hayata yeniden başlamaya hazırlanır gibiyim. Ne güzel şey inanmak, Allah'in yüceliği karşısında eğilmek. Bu dönem zarfında, ayağımın nereye bastığının bile farkında olmadan dolaştım durdum. Neler düşünmedim ki! ... Atomlardan galaksilere, amiplerden fillere kadar, bütün "varlık" denen şeyler defalarca gözlerimin önünde resmi geçit yaptılar. Yutarcasına okuduğum kitaplardan bazılarının isimlerini zikretmek isterim: Allah ve Modern İlim, Allah Vardır, İlimden Felsefeden Dine, Niçin Allah'a İnanıyorum,

15 Hasan Onat, "Bir Üniversiteli Gencin Hatıra Defterinden Seçmeler", 16 Kasım 1974, 3-4. Hasan Onat'in bu satırlarını okuyunca, 27 Eylül 2020 tarihinde "öbür dünyaya öğrencilerinin omuzlarında" uğurlanmasının kendisi için büyük bir saadet olduğunu düşündüm. Covid-19 sebebiyle cenazesine katılanlar kalabalık değildiyse de, ilk doktora öğrencisi tarafından cenazesi kıldırıldıktan sonra, "inanmış öğrencilerinin omuzlarında" kendisinin de istediği sadelikte bir törenle ebedi istirahatgahına uğurlandı.

16 Hasan Onat, "Bir Üniversiteli Gencin Hatıra Defterinden Seçmeler", 15 Nisan 1975, 6. 
İlim İman Etmeyi Gerektirir, İlim Ahlak İman, İlmin Işığında İslâm .... Bunlardan "İlimden Felsefeden Dine" isimli kitab1 lisede iken almıştım ve okumuştum. Maalesef o zaman hiçbir şey anlamamışım. Demek ki okumak başka anlamak başka. "Niçin Allah'a İnaniyoruz", gerçekten çok enteresan bir eser. Batılı meşhur bilim adamlarından pek çoğuna Allah'a inanıp inanmadıkları sorulmuş, alınan cevaplar güzel bir şekilde düzenlenip kitap haline getirilmiş. Bir roman gibi zevkle okudum. ... Yıllar önce, patlamak zorunda olan yanardağ ilk işâreti olan dumanlarını göndermişti. Bugün ise, artık yolların ayrılış noktasına geldik galiba: Artık patlama kaçınılmaz! Ya iman, ya inkar. Şimdi o zamankinden bir farkım var: Ne aradığımı, nasıl ve nerede bulabileceğimi biliyorum. İlk yapacağım iş, o zaman okuduğum kitapları tekrar gözden geçirmek. Daha sonra da bu konu ile alâkalı bulabildiğim kitapları dikkatli bir ssekilde okumak. ... Her şeyden önce beni öylesine bunalıma doğru iten sebepleri anlamak istiyorum. Aksi takdirde probleme sihhatli bir çözüm bulmak biraz zor gibi görünüyor."

Hasan Onat, İlahiyat eğitimi sırasında çalışkanllğı, çok kitap okumas1, vaktini değerlendirmesi, konferans ve benzeri ilmî faaliyetleri takip etmesi ile tanınmaktaydı. Nasıl bir öğrenci olduğu konusunda İslam Mezhepleri Tarihi derslerine giren ve daha sonra hayatına yön verecek olan Hocası Prof. Dr. Ethem Ruhi Fiğlalı, Hasan Onat ile ilgili kendisiyle yapılan bir söyleşide şu değerli bilgileri vermiştir:

"Hasan, deyim yerinde ise, tam bana göre bir çetin cevizdi. Sınıfta ya da Fakültedeki diğer arkadaşları ile münasebetleri nasıld1, bilmiyorum; ama tahmin edebiliyorum. Herhalde onlarla sağda solda dolaşmak için boş vakte sahip olabildiğini pek sanmıyorum; ama belki akşamları onlarla iyi vakit geçirmiş olabilir. Çünkü gündüzleri kendisine verdiğim okumalar yahut takip edilecek konferans ve benzeri faaliyetleri takip zarureti yüzünden, derslerin dişında, benimle bile, oldukça seyrek görüşebilirdik. Kısaca kendisine verilen okuma ve arasstırma görevlerinin ifasındaki disiplin ve ciddiyet, benim her zaman dikkatimi ve takdirimi celp etmiştir. Hasan, sadece arkadaşları ile değil diğer hocaları ile de ağır başlı ve ciddî münasebetler kurard1. Kendisini tatmin edememiş hocalarını çekiştirirken, çok ölçülü ve mantıklı konuşurdu. O kadar ki, benimle bile bir baba-oğul arasındaki münasebet gibi, çok samimî ve güvenli olmakla beraber resmî duruşunu her zaman korumuştur. Onun bu hususlardaki hassasiyeti, öğretim üyesi arkadaşlarımın pek çoğu tarafından takdir edilmiştir. $\mathrm{O}$, sadece talebeliğinde değil, akademik hayatının bütün merhalelerinde de, sadece bana karşı değil, 
hocalarına ve herkese karşı ciddî, doğru, samimî, sevecen bir tavır sergilemiştir."17

Hasan Onat, Lisans bitirme tezini, Ethem Ruhi Fiğlalı danışmanlığında Haricilerin makalat geleneğine ait Kalhatî'nin elKeşf ve'l-Beyan adlı eseri örneklemi üzerinden "İbadiyenin İnanç Esasları" üzerine hazırladı. O, Ankara Üniversitesi İlahiyat Fakültesi "Tefsir ve Hadis Bölümü"nden 3040 numaralı öğrenci olarak 1444 numaralı diplomayla 1978-1979 ders y1l sonunda iyi derece ile mezun oldu. Kendisiyle beş y1l boyunca yurtta aynı odayı ve sonra aynı evi paylasstığı ev ve yurt arkadaşı ve en samimi sınıf arkadaşı Abdülkadir Tellioğlu, Ankara Üniversitesi İlahiyat Fakültesi 19781979 Mezunları Yıllığı'nda Hasan Onat için geleceği ile ilgili ipuçları veren şu değerlendirmeleri yaptı:

“1957 Çankırı'nın güzel bir kasabası olan Eldivan'da doğmuştur. Yatılı öğrenci olarak Yozgat Lisesini bitirmiştir. Derslerde çok soru sormasıyla tanınır. Şiir ve Öykü çalışmaları vardır. Tasavvufa karşı bir merakı olan arkadașimız tez olarak Haricilerin bir kolu olan İbadilerin inanç esasları üzerine çalışmıştır. Büyük emellerle doludur. Kendisine başarılar dileriz."

Abdülkadir Tellioğlu, daha sonra şahsıma gönderdiği bir notta, Hasan Onat'ın "öğrencilik hayatında zaman zaman her yönden fikir kitapları okurken, Konya, Adıyaman-Menzil, Ankara, İstanbul gibi merkezlerde bulunan nefis tezkiyesi ile ilgili gönül sohbetlerine katıldığını, ama hiçbirisine intisap etmediğini" ifade etmektedir. Onat, felsefe gibi tasavvufi eserleri de okuyan bir aydındi. Bu eserlerin bassinda Ahmet Yesevi'nin Divan'1, Hacı Bektaş Veli'nin Makâlât'1, Mevlana'nın Mesnevi'si ve daha pek çok klasik kaynak gelmekteydi. Yesevilik ve Bektaşilik üzerine yazdığı makaleleri, cemaat ve tarikatlarla ilgili eleștirilerindeki derinlik, onun tasavvufi düşünceye ilgisini açıkça göstermektedir. Aslında çocukluğundan itibaren kaynağ1 Türk kültüründeki Yeseviliğe ve İslam medeniyetindeki ahiliğe dayanan yaren geleneğinin yaşatıldığı bir çevrede büyüyen Hasan Onat, Ahmet Yesevi, Hacı Bektaş Veli ve Yunus Emre'nin tarihteki misyonunu yerine getiriyordu. Çünkü her zaman insan sevgisi, insan onuruna sayg1, dürüstlük ve dini hayatın kolaylaştırılmasından bahsederdi. Özellikle dini söylemin siyasetin kin ve nefret dilinden ve cemaatçilerin korku dilinden arındırılmasını isterdi. Bu yüzden siyasi partilerden, kuruluş aşamasında veya seçim dönemlerinde gelen teklifleri israrlara rağmen kabul etmedi. Onat, insanların hepsine hitap etmek istediği için kendisini bir

17 Ahmet Bağlığlu, “ Prof. Dr. Ethem Ruhi Fığlalı Hocamız İle Prof. Dr. Hasan Onat Üzerine Söyleşi”, Türk Yurdu 399 (Kasım 2020), 100. 
cemaate, tarikata ve siyasete hapsetmedi. Bu söylemiyle Türkiye'nin toplumsal birliği ve dirliğine önemli katkılar sunmuştur.

\section{Prof. Dr. Ethem Ruhi Fığlalı Tarafından Keşfedilişi ve Mezhepler Tarihçiliği Serüveni}

Hasan Onat, İlahiyat Fakültesindeki, kendi ifadesiyle "şimdiye kadar görmediğim" dediği derslere önce isınamadı. Birinci sınıfın sonlarına doğru öğretim üyesi kadrosunu tanıdıkça bakış açısı değişmeye başladı. Onun bakış açısını değiştiren hocalardan birisi Ethem Ruhi Fığlalı oldu. Onun derslerini merak eder ve gönüllü olarak takip ederdi. Hatta vefatına kadar bu konu gündeme geldiği her defasinda onun ders anlatma üslup ve yönteminden övgüyle bahsederdi. Hocası Ankara'ya gelip İlahiyat'ı ziyaret ettiğinde onu lisans veya lisansüstü derslere konuk ederdi. Hasan Onat'in ilk iki y1l derslerini takip etmesi ve bu sırada ilginç sorular sorması E. Ruhi Fığlalı'nın dikkatini çekti. 1977-1978 akademik yılı 1. yarıyıl sonlarında bir gün dersten sonra kendisini odasına çağırarak, onun nereli ve hangi okuldan mezun olduğu hakkında bilgiler aldı. E. Ruhi Fığlalı'nın gözü, Hasan'ı tuttu. Çünkü kendisiyle görüşmesinde, onun "lisede matematiğin ve felsefenin beşerî bilimleri anlama ve kavrama hususlarında vazgeçilemeyecek bir anahtar olduğunu öğrendiğini ve bu gerçeğin farkında olduğunu" anladı. E. Ruhi Fığlalı'ya göre, kendi derslerinin ona cazip gelmesinin sebebi buydu. E. Ruhi Fığlalı, 1977-1978 akademik yılının sonunda "tam bir çetin ceviz" diye tanımladığı Hasan'ı tekrar odasına çağırıp, mezun olduktan sonra ne yapmayı hedeflediğini sordu. Hasan, öğretmenliğe başlayabileceği cevabını verdi. Bunun üzerine Fığlalı Hoca, akademik hayatı tercih edip etmeyeceğini sordu. Ancak öğrencisine cevabi söz hakkını vermeden önce akademik hayatın çileli ve zorlu bir yolculuk olduğunu; öncelikle çok iyi daktilo kullanmanın, mutlaka en az iki dili, Arapça ve bir Batı dilini sağlam bir biçimde bilmenin ve en önemlisi de senenin her gününün en az 10-12 saatini okumaya ve araştırmaya tahsis etmenin bu işin olmazsa olmazları olduğunu uzun uzun anlattı. Ardından da "Eğer bunları itirazsız üstlenebileceksen ve İslâm Mezhepleri Tarihi'ni de düşünüyorsan, 'Haydi buyur!" dedi. Hasan Onat, hocasına teşekkür etti ve cevabını, önümüzdeki öğretim yılı başında vereceğini söyleyip yanından ayrıld1. Hasan Onat, 1978-1979 Akademik yılın başında hocasını ziyaret etti ve şu cevab1 verdi: "Hocam, bütün yaz söylediklerinizi düşündüm, tarttım ve neticede rehberliğiniz devam ettiği sürece bu işin üstesinden gelebilmek için olanca gücümle çalışıp inşallah başarılı olacağıma ve dolayısıyla sizi mahcup etmeyeceğime kanaat getirdim." E. Ruhi Fiğlalı yıllar sonra onun bu cevabına yansıyan olgunluğu "Doğrusu bu, benim beklediğimin de üstünde bir 
yaklaşımdı. Ben de daha o gün kendime 'Bu iş Hasan'ındır ve Hasan da benim has evlâdım ve vârisimdir.' dedim" şeklindeki ifadeleriyle dile getirmiştir. Fığlalı Hoca, asistan kadrosunun tahsisi işiyle bizzat ilgilenerek kadrosunu Fakülte Kurulu, Üniversite ve Maliye Bakanlığı'ndan hızlı bir biçimde çıkarttı. ${ }^{18}$

Hasan Onat, "25.12.1979 tarih ve 31 say1l kararname ile Fakülte'nin İslâm Mezhepleri Tarihi Kürsüsü asistanlığına tayin edildi. Yazının kendisine tebliğ edilmesinden beş gün sonra 25.12.1979 günü Fakülte'deki görevine başladı. 05.11.1981 tarihinden itibaren 4 ay süreyle askerlik hizmetini yaptı ve 02.03.1982'de terhis oldu.

Hasan Onat, çok şanslıydı, çünkü İslam Mezhepler Tarihi'nin duayenlerinden E. Ruhi Fığlalı'nın rahle-i tedrisatına dahil oldu. Onat, 1982 yılında doktoraya başladı. Ancak Fiğlalı, İslam Enstitülerinin fakülteye dönüştürülmesiyle İzmir İlahiyat Fakültesi'ne kurucu dekan olarak atandı. Hasan Onat, hocasının İzmir'e gidişine çok üzüldü. Çünkü onun yükü artmıștı, sadece tezle ilgilenmedi, aynı zamanda İslam Mezhepler Tarihi derslerine de girmeye başladı. Ancak hocası onu yalnız bırakmadı ve çalışmalarını yakından takip etti. Nurten Hanım'ın aktardığına göre, Fığlalı, doktora öğrencisini ve meslektaşını haftada iki gün mutlaka arayıp sormayı sürdürdü.

Hasan Onat, doktora yaptığ1 dönemde, 1983 y1lının 7 Ağustos'unda Nurten Hanım ile evlendi. Bu evlilikten Oğuz ve Yavuz isimli iki erkek çocukları oldu. Onat, zaman zaman İzmir'e giderek tez danışmanına tezi hakkında karşılaştı̆g 1 sorunlarla ilgili bilgiler verdi. Doktorasının ikinci veya üçüncü yılında, Hasan Onat, eşi Nurten Hanım ile birlikte E. Ruhi Fığlalı'yla görüşmek üzere İzmir'e gittiğinde Fığlalı Hoca, Nurten Hanım'a Hasan Onat'ı nasıl keşfettiğinden bahsetti ve aşağıdaki tavsiyelerde bulundu:

“Bak Nurten kızım. Hasan'ı ben öğrenciliğinde keşfettim ve bir sürü hocanın elinden aldım, kendime asistan yaptım. Ben Hasan'1 nasıl görüyorum biliyor musun?" "Nasıl görüyorsunuz hocam?" diye sordum. "Hasan'ı Türkiye üzerine doğan bir güneş gibi görüyorum. Eğer o güneşi parlatırsan, senin eserindir, derim. Eğer o güneşi soldurursan bu senin vebalindir, derim."19

1979 yılında doktoraya başlayan Hasan Onat, Ankara Üniversitesi Sosyal Bilimler Enstitüsüne bağl1 Kelam ve İslam Felsefesi Anabilim Dalı'nda E. Ruhi Fığlalı'nın danışmanlığında hazırladığı "Emeviler

\footnotetext{
18 Bağlığlu, “ Prof. Dr. Ethem Ruhi Fığlalı Hocamız İle Prof. Dr. Hasan Onat Üzerine Söyleşi”, 99-100.

19 Üçok, "Nurten Onat Hanımefendi İle Eşi Hasan Onat Üzerine Söyleşi”, 109.
} 
Devri Şii Hareketleri" adlı teziyle 07.03.1986 yılında 101 numaralı diploma ile İlahiyat Doktoru uvanı ve yetkisini almağa hak kazandı. Onat, bu çalışmasında "fikir-hadise irtibatı" olarak bilinen ve çalışma sonrasında kendi adıyla anılan önemli bir yöntem geliştirdi. Onun bu yöntemi, sadece ilk Şii hareketlerin doğuşunda kullanılmadı. Aynı zamanda kendi danışmanlığında veya başkalarının danışmanlığında yapılan Mezhepler Tarihi ile ilgili tezlerde takip edilen bir yöntem oldu. 18.05.1987 y1lında yardımc1 doçent kadrosuna atand1; 11.10.1989 yılında da doçent oldu. 25.2.1993-25.9.1993 tarihleri arasinda İngiltere'de Londra Üniversitesi ve Manchester Üniversitesi'nde alanı ile ilgili araştırmalar yaptı. 18.05.1995 yılında profesör oldu.

\section{5. İnsan Sevgisiyle Dolu ve İnsan Onuruna Saygı Duyan Bir Mütefekkir}

Hasan Onat'in düşünce siteminin merkezinde insan sevgisi ve insan onuru vard1. Din, insan içindi ve insanın insanlığını gerçekleştirmekte bir araçtı. Hangi mezhep ve meşrepten, hangi siyasi görüş ve anlayıştan olursa olsun, ayrım yapmaksızın herkese karş1 sevgi besleyen ve sayg1 gösteren bir güzel insand1. İnsan olan, öteki değildi. Hasan Onat, özellikle benim için iyi bir dost, kardeş, arkadaş, sırdaş ve aile dostu idi. Eski biyografi eserlerinin dili ve üslubuyla onu tanımlamak gerekirse; "dürüst, nazik, mütevazi, kibar, cömert, misafirperver, kararlı, çalışkan, paylaşmayı seven, eleştiriye açık, mücadeleci, sevgi dolu, dindar, Kur'an aşı̆̆ı, insanperver, doğruları söylemekten korkmayan", bugünün değerleriyle "idealist, mücadeleci, milliyetçi, vatanperver, Türkiye sevdalıs1, duru bir Türkçe konuşan, şair, yazar, hatip, iyi bir okuyucu, kitap muhibbi, saygıl1, saygın bir İlahiyatçı, mütefekkir bir insand1."

Hasan Onat; nezaketi, kibarlığı, cömertliği, beyefendiliği ve güler yüzlülügü ile meslektassları ve sevenlerinin kalbinde taht kurdu. O, inandığ1 ve düşündüğü gibi yaşardı. O, farklı ortamlarda dikkat çekmek veya kişilere yaranmak için ya da mevki ve makam için farklı konuşmaz ve farklı davranmazdı. Olduğu gibi görünür göründüğü gibi olurdu. Onur kırıci davranışlardan uzak dururdu ve ögrencilerine de bundan uzak durmalarını tavsiye ederdi. Gazete köşe yazılarından birisinde bu konuyu şöyle gündeme taşıdı:

"Onursuzluk, bile bile zulümden yana, zalimden yana, haksız ama güçlü olandan yana tavır alarak; haklının hakkını, suçlunun hak ettiği cezasını vermemektir. Her ne sebeple olursa olsun, adaletsizlik yapan, öncelikle kendi onurunu ayaklar altına almıştır. Başkalarının 
onuru ile oynayanın, mutlaka onuru ile oynanır. İnsanoğlu, onuru ile oynanmasin 1 asla affetmez." 20

Hasan Onat; insan, insan sevgisi, insan onuru, insanın kendini gerçekleştirmesi, insan hak ve özgürlükleri üzerine pek çok makale kaleme aldı. Kendisinin Akşam Gazetesi'nde yayınlanan bir köşe yazısındaki şu tespitleri "insan sevgisi ve önemi” konusundaki görüşlerini özetler niteliktedir:

"Günümüz insanının sevgi, sayg1 ve hoşgörüye her zamankinden daha çok ihtiyacı vardır. Özellikle, insan sevgisinin yeniden keşfedilmesi gerekmektedir. Sevgi insanın hamurunda vardır. Önemli olan bu sevginin keşfedilmesi, açığa çıkartılması ve geliştirilmesidir. İnsanı insan yapan değerlerin başında "insan sevgisi" gelmektedir. Çünkü "insan olmak", dili, rengi, ırkı ne olursa olsun başlı başına bir "değer"dir. Bu sevgi, genel-geçer bir nitelik taşımaktadır ve kendine özgü bir anlamı ve kutsallığı vardır. İçinde yaşadığımız zaman diliminde, sözünü ettiğimiz insan sevgisi iyice yıpranmıştır. Kin, nefret, sevgisizlik, benmerkezcilik, "insan" kavramının bile içeriğinden çok şeyler yitirmesine yol açmaktadır. Bütün insanlığın "insan sevgisine" şiddetle muhtaç olduğu bir zaman diliminde yaşamaktayız. Bilim ve teknolojide zirveyi zorlayan, tarihinin en yoğun bilgi birikimine ulaşan insanlık, belki de sevgisizliğin doruk noktasına ulaştığı talihsiz bir dönemdedir. Kan, kin, nefret ve gözyaş1, günümüzün en belirgin özelliklerinden olmuştur. İnsanlık, insanlık adına, gelişme adına, uygarlık adına, bir anlamda "bindiği dalı kesmekte", "insan kavramı" anlamını ve zenginliğini kaybetmektedir. İhtiyar dünyamı, sevgisizliğin ortalığ1 kasıp kavurduğu kötü bir dönemden geçmektedir."21

Hasan Onat, akademiden ve akademi dışından sağcı, solcu, İslamc1, Laik, Şii, Sünni ve Alevi çevrelerden çok sayıda dost biriktirdi. Kendisinin Fakültedeki dostlarından olan Prof. Dr. Halis Albayrak, Türk Ocakları'nın düzenlediği çevrimiçi bir panelde onu "Çağının Mümini" veya "Çağının Müslümanı" olarak tanımlamış ve bunu şu şekilde açıklamıştır:

"Sireti ve sureti güzel insan idi, dedikodu bilmezdi. Otobüste de ayaküstü de olsa mutlaka fikrî mevzusu vard1. Derdi vardı. İnsan ve İslam arasındaki kurduğu ilişkiyi, sadece anlatmadı, etrafında hem anlattı hem de yaşadı. Çağının mümini idi. Çağının Müslümanı idi. Kök değerlerine çok bağl1 kişilik idi. Bunlar, temel insani değerler ve İslam ile örtüssen değerlerdi. Gelecekte neler olabileceğini öngören

${ }^{20}$ Hasan Onat, "İnsan Onurunu Adalet Yüceltir”, Hürriyet (20 Temmuz 2013), 6.

21 Hasan Onat, "Unuttuğumuz Bir Gerçek: Mü'minler Kardeştir”, Akşam (31 Ağustos 2010), 17. 
birisi idi. Ânı değerlendirmenin çok önemli olduğuna inanırdı ve böyle yaşard1. Etrafına 1şık ve bilgi saçard1. Çağının mümini olmak çok önemli idi. Tarihte kalan formlarla ortaya konulacak müminliğin Müslümanları nerelere getirdiği ve nerelere taşıdığını görebiliyoruz. Değerleri çağın icaplarına ve ihtiyaçlarına göre yeniden biçimlendirmek, yeniden tanımlamak ve yeniden ihya etmek adına bir çaba olmadığı sürece çağının mümini olunamaz."22

Hasan Onat, çok misafirperver birisiydi. Ankara'da şaşaadan uzak mütevazi bir hayat sürdü. Ailece ziyaretlerimizde bizi kapıda karşılardı. Dönüşte, aracımız yoksa bizi eve kadar aracıyla bırakırdı. Daha sonra çok sevdiği Eldivan'da kendi elleriyle dikip yetiştirdiği güzel bir bahçe içerisine güzel bir ev yaptı. Misafirlerini eşi Nurten Hanım'la birlikte burada ağırlardı. Fakültemizden ve tanıdığı dostlarından pek çoğu onun misafiri oldu, başta kiraz olmak üzere kendi yetiştirdiği meyvelerden tattı. Özellikle kiraz mevsiminde misafirleri eksik olmazdı. Bazı bilimsel toplantılara ve görüşmelere burası ev sahipliği yapıyordu.

\section{Dik Duran, Eleştirel Yaklaşan ve Cesaretle Fikirlerini Yazan ve Konuşan Bir Bilim İnsanı}

Hasan Onat, pek çok kişinin konuşmaktan korktuğu 28 Şubat ve 15 Temmuz dönemlerinde ülkemizin en önemli sorunlarının başında gelen eğitim, din eğitimi ve öğretimi, Alevilik-Bektaşilik, cemaatler, laiklik, sekülerizm ve demokrasi gibi konularda yazmaktan ve konuşmaktan çekinmedi. Yurtiçi ve yurtdişında onlarca sempozyuma tebliğler sundu, yüzlerce konferans verdi. Akademik hayatında haksızlıklara karşı dik duruşu ve eleştirel bakışı, cesareti, herkesin takdirini ve beğenisini kazandi.

Sorunlara sosyolojik, psikolojik ve felsefi açılardan bakabilme birikimine sahip nadir ilahiyatçılardan idi. İlahiyat çevrelerinde ifade edilmekten korkulan pek çok sorunu cesaretle her ortamda söyledi. Özellikle din-siyaset ve din-hukuk ilişkisine dair özgün görüşleri bunlar arasındayd1. Laikliği, din ve vicdan özgürlüğü açısından Türkiye için önemli bir şans olarak görürdü. Türkiye'nin hassas sorunlarından kadın sorunu, cemaatler ve tarikatlar sorunu ve Alevilik-Bektaşilik üzerine önemli çözüm önerilerinde bulundu. İslam dünyasının kurtuluşunu akıl-din veya din-bilim arasındaki ilişkinin doğru bir şekilde kurulmasına bağlardı.

\footnotetext{
22 Halis Albayrak, "Bir Fikir ve Bilim Adamı Olarak Hasan Onat Paneli", Türk Ocağı TV (20 Kasım 2020),

https://www.youtube.com/watch?v=GrZ7qpvu4zE\&t=1358s, 19:00-22:40.
} 
Hayatını ilmi ve İslam'ı sevdirmeye adamış olan Hasan Onat, Türkiye'deki dinî toplumsal yapılardan tarikat ve cemaatlara eleştirel yaklaşımından asla taviz vermedi. ${ }^{23} \mathrm{Bu}$ sebeple FETÖ ve IŞID, Hasan Onat'i hedef tahtası yapmışt1.

\section{7. Çok Yönlü Okuyan, Paylaşan ve Tartışan Bir Mütefekkir}

Hasan Onat denince okumak, paylaşmak, düşünmek ve tartışmak akla gelirdi. Okumak ve okutmak onun tutkusu idi. Kendi deyimiyle "çok okuduğunda az yazan; az okuduğunda çok yazan ve okuduğunu paylaşan" bir akademisyen idi. Özellikle Kur'an'ı okuyup anlamak onun hayat felsefesi haline gelmişti. Her yıl Ramazan ayında çeşitli çevirileri karşılaştırarak incelerdi. Kur'an'ın inşa etmek istediği insana kafa yoruyordu ve bu konuda bir kitap hazırlıyordu. Dinî sorunların çözümünde Kur'an'ı doğru anlamaktan geçtiğine inanırdı. İyi bir Müslüman olmanın şartının Kur'an'ı doğru anlamak ve onun değerlerini içselleștirmekten geçtiğine fikrindeydi.24 Hayatını Kur'an'a adaması ve günümüz insanını onun değerlerinden haberdar etmesi için gösterdiği gayretleri sebebiyle kendisi 'Kur'an muhibbi' olarak tanımlanmayı hak ediyordu. Aynı zamanda Hz. Muhammed'i doğru anlamak için Siret konusunda yazılan her kitabı okurdu. Hatta

${ }^{23}$ İbrahim Maraş, "Hasan Onat'in Tarikat ve Cemaatlere Yönelik Eleştirileri”, Türk Yurdu 399 (Kasim 2020), 74-77.

24 O, bütün yazılarında Müslüman için Kuran'ın önemini hep vurguladı ve onu anlamanın önündeki tüm engelleri kaldırmaya çalıştı. Bunlardan birisinde bu konuda şu tespitlerde bulundu: "Kur'ân, anlașılmak için gönderilmiș bir kitaptır. Kur'ân'ın amacı, insanoğlunun gerçekleri görmesini sağlamak ve insanlığını en iyi şekilde inşa etmesine yardımcı olmaktır. Kur'an, neredeyse birebir insana tekabül eden bir kitaptır. İnsanın duygusal iniş çıkışlarını, akli yükselișlerini Kur'an'dan takip etmek mümkündür. Kur'an, insanı kendi gerçekliği ile yüzleşmeye çağırır. Kur'an, insana kendisini anlatır. Bu ise, ancak onu doğru anlamakla mümkün olabilir. Kur'an'ı anlamanın önünde hiçbir engelin olamayacağını belirtmekte fayda vardır. Her insan, kendi yeteneğine, bilgi birikimine göre, anlama konusundaki çabasına göre Kur'an'ı anlayabilir. Daha iyi anlayabilmek, daha çok çabayı, daha çok samimiyeti ve daha iyi bir donanımı gerektirir. Kur'an okumanın tek bir ön koşulu vardır: Kur'an okumaya başlarken "kovulmuş şeytana karşı Allah'a sığınmak" (16/98). Bunu, insanın ön yargılardan arınmıs olarak, bilgiye/öğrenmeye açık bir şekilde Kur'an okumaya başlaması şeklinde yorumlamak da mümkündür. Kur'an'ın anlașılamayacağını iddia etmek, açıkça Kur'an'a ve $\mathrm{Hz}$. Muhammed'in tatbikatına aykırıdır. Hz. Muhammed'in en önemli görevi, Kur'an'1 insanlara ulaştırmak ve insanları vahiyle uyarmaktır. Hz. Muhammed, bütün peygamberlik hayatı boyunca, insanları Kur'an'la buluşturabilmek için çırpınmıștır. Her insan, Kur'an'ı anlayabildiği ve onun değerlerini içselleştirebildiği kadar Müslüman olabilir." (Hasan Onat, "Kur'an Anlaşılmak İçin İndirilmiştir", Akşam (12 Ağustos 2010), 17. 
kendisi Hz. Muhammed'in hayatı ile ilgili bir eser yazmayı planliyordu.

Hasan Onat, okuduğunu eleştiri süzgecinden geçiren ve ifadesi zor bilimsel bulguları, "en son ulaştığım sonuca göre" veya "en son tespitlerime göre" diye başlayarak herkesin anlayacağı arı ve duru bir Türkçe ile anlatabilen bir bilim adamı idi. Akademik üslubu oldukça bilimsel ve edebî idi. Radyoculuğunun, televizyonculuğun ve çok kitap okumasının bir sonucu olsa gerek, diksiyonu ve anlatım dili ile başkalarından önde idi. Yazıları şiir gibiydi. Bilimsel açıdan iyi bir ilim adamı olmasının yanı sıra mütefekkir, aydın ve sanat ruhlu bir kimseydi. Kendisini sadece alanına hapseden ve basska alanlarla ilgilenmeyen bir akademisyen değildi. İlahiyat alanını ve bilim dünyasını ilgilendiren, Türkiye'nin ve İslam dünyasının gündeminde olan dinî, toplumsal ve siyasi meselelerle yakından ilgilenen, bu hususlarda genis okumalar yapan ve yazdığı birkaç makaleyle tarihe not düşen aydın sorumluluğuna sahip bir araştırmacı idi. Küreselleşme, sosyal değişme, modernizm, postmodernizm, fenomenoloji, tarih felsefesi, yapay zeka, öğrenen algoritma, medeniyet ve kültür, çocuk istismarı, kadın sorunu, laiklik ve demokrasi üzerine yazılar yazan ve konuşan ilk İlahiyatçılardandı. Çok yönlü okuması ve farklı dünya görüşüne sahip aydınlarla aynı fikrî tartışma ortamlarında yer alması, her kesimle iyi ilişkiler kurmasını ve fikir alışverişinde bulunmasını sağlıyordu. Onun okuma tutkusu, günlüklerine de yansımıștır. Günlüklerinden hareketle hangi yıllarda hangi kitapları okuduğu ve onların onun bilimsel şahsiyetini nasıl şekillendirdiği bağımsız araştırmalarla ortaya konulabilecek bir konudur.

Hasan Onat, öğrenciler için ders dişında kitap okutarak ilmî tartışma ortamları oluşturma ve fikirleri paylaşma imkanı yaratma konusunda da iyi bir örnekti. Kendisi oldukça farklı alanlarla ilgilenen bir entelektüel idi. Onun girişimleriyle benim de katıldığım bir akademisyen grupla, -saniyorum 1994-995 y1llar1 idi- Felsefe okumalar1 yapt1k.

Hasan Onat, Sosyoloji, Psiskoloji, Antropoloji, Siyaset, Felsefe, Kültür, Edebiyat alanında kitapların yer aldığı zengin bir kütüphaneye sahipti. Kütüphanesinin en özgün yanlarından birisi, Mezhepler Tarihi ve Çağdaş İslam akımları ile ilgi önemli bir kolleksiyonu barındırıyor olmasidır.

Hasan Onat'in emekli olunca yapmak istediği işlerden birisi, Emek veya Bahçeli'de gençler için bir Kitap Kafe açmaktı. Böylece, ihmal edildiğine inandığ gençlere okuma, paylaşma ve tartışma ortamı yaratmak istiyordu. 


\section{Radyo ve Televizyonlarda Program Yapımcisi ve Sunucusu}

Hasan Onat, uzun süreli radyo ve televizyon programlarında metin yazma, konuşma ve sunuculuk yapma gibi görevler üstlendi. Bu konuda geniş bir tecrübeye sahipti. Türkiye'nin Sesi Radyosu'nda [TSR] 1986 y1lında "Din ve Dünya" isimli programla başlayan radyoculuğu, daha sonra "Dini Bilgimiz Dini Kültürümüz"le, 1988 yılından itibaren "Gençlik ve Din" programı ile devam etmişti. Yıllar içinde, bir yandan Gençlik ve Din programı devam ederken, "Hasan Onat'la On Dakika" ve peşinden "Din, Ak1l, Bilim” programlarıyla devam etti. 24 y1llık bir radyoculuk serüveni vard1. O, son programda "gençlik ve gençliğin sorunları üzerinde yoğunlaşmış, özellikle gençlerin din alanındaki sorunlarının çözümüne bilimsel/ doğru bilgi ile katkıda bulunma" çabası içerisinde olmuştur. TSR'deki metinli konuşmaları, Radyo Konuşmaları adıyla yayın aşamasına gelmiş bulunmaktadir.

Hasan Onat, radyoculuk serüvenini “Türkiye'nin Sesi Radyosu'nda 24 Yillik Sessiz Yolculuk" adlı bir hatırat yazısında kısaca anlattı. Bu yazıda, TSR'deki programlarla büyük işler başardığını yurt dışına yaptığı seyahatlerde Avrupa'da yaşayan ve programları dinleyenlerin izlenimlerinden ögrendi. Bu konudaki olumlu tepkilerle ilgili gerek doğrudan dinleyicilerle görüşmeleri, gerekse arşivinde sakladığı dinleyici mektupları yoluyla bazı anılarına bu yazıda yer verdi. Dinleyicilerden birisi, kendisine haklı olarak şunu söyledi: "Siz bizim elimiz, ayağımız, gözümüz ve kulağımız oldunuz."25

Hasan Onat, oldukça didaktik programlar yapard1. Okuduğu kitaplardan paylaştığı önemli bilgileri, verdiği kitap isimleri ve notları Avrupa'da yaşayan Türk işçileri ve aileleri tarafından merakla izlendi. Dinleyiciler bazen mektupla bu bilgilerin asıl kaynağını ondan istedi. Örneğin Almanya'dan bir anne, programda ismini duyduğu ve Onat tarafından okunan "Pulsuz Dilekçe"nin asıl metnini mektupla ondan istedi. ${ }^{26}$

25 (Programın etkisi ile ilgili diğer örnekler için bkz.: Hasan Onat, "24 Yıllık Sessiz Yolculuktan Akılda Kalanlar”, Prof. Dr. Hasan Onat (Erişim 07 Haziran 2021). http://www.hasanonat.net/index.php/64-24-y-11-k-sessiz-yolculuktan-aklda-kalanlar

${ }^{26}$ Hasan Onat, bir yazısında bununla ilgili şu bilgiyi vermektedir: "Bir programda merhum Atalay Yörükoğlu'nun "Çocuk Ruh Sağlığı” isimli kitabında yer alan "Pulsuz Dilekçe"yi seslendirmiştim. Bu programdan sonra, Almanya'dan mektup yazan bir hanım dinleyicimizin arssimizde sakladığımızın mektubundaki şu satırları, yaptığımız işin anlamlı olduğunu fark etmek, daha iştiyakla programlara sarılmak için tam bir uyarı idi: "Lütfen o mektubu 
Hasan Onat'ın TSR'deki programlarının Avrupa'da yaşayan Türk dinleyiciler üzerindeki etkileri bunlardan ibaret değildir. Programı dinleyenler, notlar alıp dinleyemeyenlerle bu bilgileri paylaşıyorlardı. $\mathrm{Bu}$ yolla Avrupa'da farklı bir kültürel atmosferde yaşayan Türk ailelerin İslam ile var olmalarını, İslam'ı yaşamalarını kolaylaştırmalarını ve kimliklerini kaybetmemelerini sağlıyordu. Onun arşivinde, evinden ve issyerinden dinleyenlerin yanı sıra hapishaneden dinleyip program dolayısıyla kendisine gönderilen bazı mektuplar bulunmaktadır. Onat, programlarının birisinde zaruret durumunda öğle ve ikindinin veya akşam ile yatsının birlikte kılınmasının caiz olduğundan bahsetti ve vardiye çalışan işçilerin bu şekilde namazlarını kılabileceklerini söyledi. Dinî hayatı kolaylaştıran bu bilgiler içeren programları hiç kaçırmayan Şahin Hocaoğlu isminde bir dinleyici, yazdığı mektupta programları övdü ve Hasan Onat'tan namazları birleştirme konusunda daha ayrıntılı bilgi istedi. 06.03.1988 tarihli bu mektubun başlangıcında programlarla ilgili şu değerlendirmeler yer almaktadır:

“Şu anda Batı Almanya'da işçi olarak çalışmaktayım. Radyo aracılığı ile yapmış olduğunuz dinî konulardaki yayınlarınızı her fırsatta dinliyorum ve bugüne kadar birçok bilgi sahibi oldum. Öğrendiğim bilgileri de her firsatta dinlemeyen diğer Din kardeşlerime anlatmaya çalışıorum." 27

Hasan Onat'ın televizyon tecrübesine gelince, televizyonculuğa ilk defa Kanal A televizyonunda 2005-2007 yıllarında "İslâm Dün Bugün Yarın" adıyla Uygur Aktan ile birlikte yaptığı ve ilk üç programa "İmam Maturidi ve Maturidiliği” konuşmak üzere konuk olarak beni de aldıkları programlara sunuculuk ile bassladı. Sonra ATA TV'de 2008-2009 yılları arasında "Kökler ve Değerler" adıyla haftada bir yayılanan, 2009 yılında aynı adla HALK TV'de devam eden programlar yaptı. Daha sonra Türkmeneli TV'de ve bazı ulusal televizyon kanalında programlar yaptı.

Hasan Onat, Türkmeneli Televizyonu'nda 2015-2017 y1llar1 arasında "İslam ve Hayat" adlı bir program yaptı ve iki sezon boyunca toplam 58 bölüm çekti. "İslam ve Hayat" programında, her hafta farklı konu ve konuklarıyla Kur'an ve insan ilişkilerini ele aldı. Hasan Onat, Tufan Gündüz ile birlikte "Hilalin Issığında" adlı 15 bölümden

adresime gönderir misiniz? Ben ilk defa o programdan sonra, çocuklarımın sesine kulak vermem gerektiğini anladım ve çocuklarımla iletişim biçimimiz değişti. Artık çocuklarımı anlamak için çaba sarf ediyorum....”. Bkz.: Onat, "24 Yillık Sessiz Yolculuktan Akılda Kalanlar", (Erişim 07 Haziran 2021). http:/ / www.hasanonat.net/index.php/64-24-y-11-k-sessiz-yolculuktan-aklda-kalanlar.

27 Mektuplar Hasan Onat'ın Özel Arşivinde saklanmaktadır. 
oluşan bir program yaptı. Din ve tarih konularının konuşulup tartış1ldığ bu program, bir sezon sürdü. 2018-2019 sezonunda ise, Türkmeneli Televizyon sunucularından Sibel Yazıcı ile beraber 29 bölümden oluşan "Geçmişten Günümüze" adlı bir program yaptı. Bir sezon devam eden bu programda aile, toplum, insan ilişkileri, İslam ahlakı gibi konular konuşuldu. 2019-2020 sezonunda ise, Hasan Onat ve Remziye Ege'nin beraber yaptığı "Kendini Bilmek" program1 18 bölüm olarak çekildi. Programda Peygamber Efendimizin hayat1, kadınlar ve çocukların eğitimi, din ve çocuk ilişkisi gibi konular ele alind1.

Hasan Onat bunların dışında pek çok televizyon kanalında gerçekleştirilen dinî ve kültürel tartışma programlarına, söyleşilere, çevrimiçi veya yüz yüze gerçekleştirilen seminer ve konferanslara katılarak bilim adamı sorumluluğu ve vakarı ile insanları din konusunda doğru bilgilendirmeye çalıștı. Onun hedefi, fikirlerini etkisi oldukça güçlü olan bu araçlar yoluyla milyonlara duyurmaktı ve dokunabildiği kadar fazla insanın kalbine dokunmaktı. Amacı bir kişi de olsa düşünce dünyasına ve zihnine ne zaman yeşereceği belli olmayan fikir tohumları serpmekti. Bu sebeple televizyon programlarına veya çevrimiçi yayınlara katılma konusunda hiçbir teklifi geri çevirmezdi.

Tespit edebildiğimiz kadarıla en son katıldığı televizyon programı, YouTube üzerinden yayın yapan Veryansın TV'de 27.09.2020 tarihinde -ilginç bir tesadüftür- toprağa verildiği gün bant kaydından yayınlanan programdır. Erdem Atay moderatörlüğünde "Akılla İmanın Bağını Kurmak / Düşünmemeyi Telkin Etmek Şeytan İşidir!" adıyla çekildi. ${ }^{28}$ Ancak ne zaman çekildiğine dair, maalesef bir bilgi yoktur. Hasan Onat'in son sözlerini Mâturîdî'nin aklı kullanmayanlarla ilgili eleştirisiyle ve ona getirdiği yorumuyla bitirmesi oldukça dikkat çekicidir:

"Düşünmemeyi telkin eden her türlü his şeytan işidir. Kim akla karş1 çıkıyorsa, kim düşünmeyiniz diyorsa, kim anlayamazsınız diyorsa, kim Kur'an anlaşılmaz diyorsa, kim bilim karşıtlığ yapıyorsa, kusura bakmasın ya şeytandır, ya da şeytanlaşmıştır."

\section{Hasan Onat'ın Bilimsel Calıșmaları: Kitap ve Makaleleri}

Hasan Onat'in okuyucu ile buluşan ilk bilimsel araștırması, Emeviler Devri Şii Hareketleri adıyla yayınlanan doktora tezidir. Daha sonra tarihsel sırasıyla İngilizce, Arapça ve Türkçe olarak yayınlanan Yirminci Asırda Şiilik ve İran Devrimi, Türkiye'de Din Anlayışında

28 Hasan Onat, "Pankuş", Veryansin Tv. 27 Eylül 2020. https://www.youtube. $\mathrm{com} /$ watch? $\mathrm{v}=07 \mathrm{NqeIsjVao \& t}=27 \mathrm{~s}$ 
Değişim Süreci ve İslam Ortak Paydası ve İslam Gerçeği gibi çalışmaları yayınlandi.

Hasan Onat, gerek kitap düzeyindeki çalışmalarında gerekse tebliğleri, makaleleri, söyleşileri, köşe yazıları ve raporlarında Türkiye'nin gündeminden düşmeyen İslam Mezhepleri, Şiilik, Alevilik, Kızılbaşlık, Bektaşilik, Maturidilik, Din anlayışı, küreselleşme, İslam'da kadın, şiddet ve terör, medeniyet tasavvuru, İlahiyat bilimlerinde yöntem, tarikatlar ve cemaatler konusuyla ilgili sorunları cesaretle ve bilim adamı duyarlılığıyla analiz etti.

Hasan Onat, araştırmalarında bilimsel tarafsızlığa büyük özen gösterdi. Şiilik başta olmak üzere hiçbir mezhebe karş1 herhangi bir önyargıya sahip değildi. Onların doğru anlaşılması için birinci el kaynaklarına başvurmanın gerekliliğine inanan bir bilim adamı idi. $\mathrm{Bu}$ sebeple Şia ve diğer mezheplerin Arapça klasik kaynakların çevirilerinde yer aldı. Kitap ve makale çalışmaları, televizyon programları ve Şiilik üzerine yaptırdığı yirmiye yakın master ve doktora teziyle Şiiliğin Türkiye'de doğru anlaşılmasına ve Şiî-Sünnî kutuplaşmasının önüne geçilmesine önemli katkılarda bulundu. Başka bir ifade ile Şiilik üzerine yaptığı çalışmalar ve yaptırdığı tezler ile alanda yeni bir çığır açtı. Onun Şiilik ile ilgili çalışmalarından habersiz olan bazı kimseler onu "Şiiliği messrulaştırmak" ile, bazıları da "sınıflarda Şii düşmanlığı yapmakla" itham etti. Her iki iddia da onun için bir iftiradır. Onun İran Şiilerinden ve Türkiye'deki Caferilerden çok sayıda dostu vardı.

Hasan Onat, ISAV tarafindan 13-15 Şubat 1993 tarihinde gerçekleştirilen Milletlerarası Tarihte ve Günümüzde Şiilik Sempozyumu öncesinde "Tarihte ve Günümüzde Şiilik Sempozyumuna hazırlık amaciyla" 16-30 Eylül 1991 tarihleri arasında düzenlenen İran seyahatine katılanlar arasındaydı. Onun eleştirileri, Şiiliği devlet ideolojisi haline getiren ve "İran İslam Devrimi" adı altında Şiilik ihraç etmeye çalışan İran'a idi. Kendisinin bu konudaki duyarlılığını ve İran'ın mezhebî politikasına yönelik eleştirilerini Şiilik aleyhtarlığı olarak görmek doğru değildir. Bu iddialar, onun konuyla ilgili makale, kitap ve konuşmalarına dayanmayan ve ilmî değer taşımayan dedikodulardan ibarettir. Onun İhsan İlahi Zahir'in Şii itikadını elesstiren ve hissi değerlendirmeleri de içinde barındıran Şia'nın Kur'ân İmamet ve Takiyye Anlayışı adlı çalışmasını Sabri Hizmetli ile birlikte Türkçe'ye çevirmesi, bu eserdeki bütün fikirlere katıldığı anlamına gelmez. Bu kitabın, İran'ın "İslam devrimi" kılıfı altında Şiilik ihracı siyasetinin önüne geçebilmek amacıyla yazıldığı ve Türkçe'ye çevrildiği ortadadır. Doktora çalışması sonrasında Şiiliğe ait yazdığı makaleleri incelendiğinde, Onat'in bu kitaptaki bazı hissî yaklaşımları kabul etmediği açıkça görülecektir. Onun Şiiliğe dair çalışmaları, ileride 
yüksek lisans ve doktora tezlerine konu olacak düzeyde ve genişliktedir. İlmî duyarlılık, Onat'ın konuyla ilgili çalışmalarının tamamını inceledikten sonra bu konuda değerlendirmeler yapmayı gerektirir.

Hasan Onat, sadece SSia'nın değil diğer mezheplerin firak ve makalat geleneğiyle de ilgilendi. Mutezilî Naşî el-Ekber'in Mesấilü'lİmâme'sinin çevirisi üzerinde çalışıyordu. Bu eser, makalat ve fırak geleneğinin önemli kaynaklarındand. Mezheplerin imamet anlayışlarını karşılaştırmalı olarak incelemenin ilk örneklerinden birisini temsil eden bu eserin çevirisi, Şia'nın İmamet nazariyesinin doğru anlaşılmasına büyük katkı sağlayacaktı. Ancak maalesef ömrü vefa etmedi. Bu eseri tamamlayıp yayınlamak sorumluluğu bize kald1.

Hasan Onat, bir grup meslektaşı ile İmam-Hatip Liseleri için Temel Dini Bilgiler (Ankara 2002), Kelam (Ankara 2003 ve Kelam Ders Kitabr (Ankara 1994) adını tassıyan ders kitapları yazdı. Editörlüğünü yaptığı İslam'a Yeni Yaklaşımlar (ed. Hasan Onat, Eskişehir 1999), İslam Düşünce Ekolleri Tarihi (ed. Hasan Onat, Ankara 2006) ve İslam Mezhepleri Tarihi El Kitabı gibi çalışmalarla Mezhepler Tarihi alanına önemli katkılarda bulundu. Hasan Onat, mesaisini sadece okumaya, bilimsel kitap ve ders kitapları hazırlamaya hasretmemiş, çok sayıda makale, söyleşi, gazete köșe yazıları ve radyo konuşmaları türünden yayınlar da yapmıștır. Ayrıca mezhepler tarihi ile ilgili Türkiye Diyanet Vakfi İslam Ansiklopedisine dokuz madde yazmıştır.

Hasan Onat, yurt içinde yayınlanan Dini Araştırmalar Dergisi, İslami Araştırmalar Dergisi, İslamiyât Dergisi, Hitit Üniversitesi İlahiyat Dergisi, Ankara Üniversitesi Ilahiyat Fakültesi Dergisi, Ondokuz Mayıs Üniversitesi İahiyat Fakültesi Dergisi, Dokuz Eylül Üniversitesi Illahiyat Fakültesi Dergisi gibi dergilerde hakemlik yaptı. İngilizce yayınlanan Turkish Journal Shiite Studies / Şiilik Araştırmaları Dergisi’nin genel editörlüğünü, Türkçe yayınlanan Demokrasi Platformu Dergisi'nin Türkiye'de Cemaatler adıyla çıkan 3 sayısının sayı editörlüğü yürüttü. Türk Ocakları Hars Heyeti üyesi olarak, ocağın çalışmalarına katkıda bulundu. Ayrıca 38. ICANAS Kongresi (2006) Ulusal Düzenleme Kurulu Üyeliği, Akademik Ortadoğu Dergisi Yayın Kurulu Üyeliği, İslami Araştırmalar Dergisi Yayın Kurulu Üyeliği, Gazi Üniversitesi Hacı Bektaş-ı Veli Araştırmaları Dergisi Bilim Kurulu Üyeliği, Demokrasi Platformu Dergisi Danışma Kurulu Üyeliği yaptı. Yurt dişında yayınlanan Forscehungszzeitschriff über Alevitentum und Bektaschitentum/Alevilik-Bektaşilik Araştırmaları Dergisi'nde Yayın Kurulu üyesi idi. 
Hasan Onat, ulusal projelerden 17.12.2017 tarihinde başlayıp üç yıl süren "İslam Tarihi ve Medeniyet" projesinde "araştırmacı" olarak; 15.03.2015 tarihinde başlayan ve üç yıl süren "Alevilik Sözlü Kültür Tespiti" projesinde "danışman" olarak çalıştı. Almanya Eugen Biser Vakfı ve Ankara Üniversitesi'nin ortak çalışması olarak başlayan ve yedi yıl süren Arapça, Almanca ve Türkçe yayınlanan "İslamiyetHristiyanlık Kavramları Sözlüğü"(Ankara 2013) adlı projede madde yazarı olarak yer aldı. Ayrıca Kur'ân Medeniyeti Projesi'nde (Gök Yayınc1lık, Ankara. 2018-2020) birlikte çalışmaktaydık.

Hasan Onat, kendisin de belirttiği gibi, okumaktan yazmaya zaman bulamad1. Okumaya yoğunlaştığ 1 dönemlerde az yazd1; yazmaya ağırlık verdiği dönemlerde az okudu. Aslında onun hayatına birincisi hakim oldu. Ancak okuduğu kitaplardan aldığı notlara bakılırsa, eğer ömrü vefa etseydi, 5-10 kitap kaleme alabilecek kadar bilgi topladı. Belki uzun yıllara yayılan araştırmalarının mahsulünü son zamanlarda kitaplaştırmayı düşündüğünden böyle yaptı. Birkaç defa yayın konusunda, hazır olanlara destek verelim ve hızlandıralım dediğimde "evet doğru söylüyorsun, bazı şeyleri geciktiriyoruz." şeklinde cevap verdi. Birkaç yayınevi, kendisiyle görüştü; ancak tamamını dizi halinde yayınlama konusunda anlaşma sağlanamadı. Bununla birlikte bazı çalışmalarını yayın aşamasına getirmek için meslektaşlarından ve öğrencilerinden destek almaya başladığını biliyoruz.

Hasan Onat'ın basım aşamasına gelmiș, ama henüz yayınlanmamıs Sorularla İslam Mezhepleri; Küreselleşme, Din, Terör ve Güven Kültürü; Sosyal Bilimler Metodolojisi; Radyo Konuşmalari; Gazete Köşe Yazıları; Kur'an'in İnşa Etmek İstediği İnsan ve Din Anlayışımız Üzerine Denemeler başlıkları altında yedi ayrı kitabı yayınlanmayı beklemektedir. Onun ilmî eserlerini, belli bir süreç içerisinde okuyucuyla buluşturmak için çalışmalarımız sürmektedir.

Hasan Onat, başarılı ilmî araştırmalar yapması, pek çok öğrenci yetisstirmesi ve görüşlerini her ortamda korkmadan cesaretle yazmas1 ve konuşması sebebiyle Maturidi-Yesevi Otağı İlmi ve Kelami Araştırmalar Derneği tarafından düzenlenen 31 Ağustos-1-2 Eylül 2015 Safranbolu'da 2. Maturidi Yesevi Otağı Kurultayı'nın ardından yapılan bir törenle "İlmin Efesi Ödülü" ile ödüllendirildi. Özbekistan'da 2018 y1linda yapilan INCSOS2018'in "Award of the best researcher 3 the year" ödülünü aldı.

\section{Hasan Onat'ın Çevirmenliği ve Çeviri Editörlüğü}

Hasan Onat, ilk çeviriyi Arapça'dan Türkçe'ye Sabri Hizmetli ile birlikte yaptı. Bu çeviri, İhsan İlahi Zahir'in SSia'nın Kur'ân İmamet ve Takiyye Anlayışı (Ankara 1984) adıyla yayınlandı. 
Hasan Onat, çeviri çalışmalarını klasik Şii kaynaklardan birisi olan Nasirüddün et-Tusî'nin İmamet Risalesi (Ankara 1996) ile devam ettirdi. Daha sonra bir grup arkadașı ile birlikte yine Şiiliğin klasik kaynaklarından Nevbahtî ve Kummî’nin fırkalarla ilgili eserlerini Şii Furkalar (Ankara 2004) adı altında tek kitap halinde Türkçe'ye çevirdi. Ayrıca uzun zamandır Mutezilî Naşî el-Ekber'in Mesâ'ilü'l-İmâme adlı eserinin çevirmek için mesai harcıyordu. Ancak bitirmeye ömrü vefa etmedi.

Hasan Onat, İngilizce'den çeviri yapmad1, ancak İngilizce'den Türkçe'ye çevrilen ve Siyasal\&Phoenix Yayınevi tarafından yayınlanan iki önemli esere editörlük yaptı. Bunlardan birincisi Marshal G. S. Hodgson'un İslam'ın Serüveni (İstanbul 2020-03); ikincisi ise İslam'ın Doğuşunda Muhammed ve İnananlar (İstanbul 2021) ${ }^{29}$ adlı kitap idi. Maalesef ikincisini, vefatından sonra yayınlandığı için göremedi.

\section{Gazete Köşe Yazarı ve Sosyal Medya Kullanıcısı}

Akademik araştırmalarının yoğunluğu, eğitimciliği, çok sayıda tez danışmanlığı, radyo ve televizyonculuğu, Din Öğretimi Genel Müdürlügü̈nde programların yapılandırılması çalışmaları, ders programları ile ilgili öğretmenlere hizmet içi eğitim kurslarında görevler üstlenmesi ve çeşitli sivil toplum örgütlerine yol göstericiliği yanı sıra, Türkiye'nin büyük tirajlı gazetelerinde Ramazan ayında "Ramazan Sayfaları" hazırladı ve köşe yazıları yazdı; aylık çıkan yerel gazetelerde ve kendi internet sitesinde makaleler yayınladı.

Hasan Onat, 2009-2012 yılları arasında Akșam Gazetesi'nde 2013-2014 yıllarında da Hürriyet Gazetesinde Ramazan ayında büyük emek mahsulü yazılar kaleme aldı. Gazetelerdeki köşe yazılarının konu başlıkları ve içeriği incelendiğinde, bunların Kur'an odaklı ve Kur'an'ın inşa etmek istediği insan odaklı olduğu görülecektir. Bu sebeple o, Ramazan ayını fırsat bilerek, köşesinde Kur'an, Hz. Peygamber, insan onuru, insan ve anlam, akıl ve bilim, din ve İslam, sosyal hayat, adalet, siyaset, evren, tarih, mezhep, gelenek, Ramazan, Oruç ve benzeri konularda okuyuculara yeni ufuklar açan, fikir yoğunluklu sıkı dokulu kısa ve öz yazılar kaleme ald1. ${ }^{30}$ Onun köşe yazılarında yoğunlaştığı en önemli konulardan

${ }^{29} \mathrm{Bu}$ eserin İngilizcesi şu adla yayınlanmıștır: Fred M. Donner, Muhammad and the Believers at the Origins of Islam, Cambridge Massachusetts, London England, 2010.

$30 \mathrm{Bu}$ yazılardan en dikkat çekici olanlarından bazılarını şöyle sıralayabiliriz: Hasan Onat, "Hayatın Anlamı İnsanın Yaratıcı Yetilerinde Gizlidir/Başarmak Hayatın Anlamını Yakalamaktır", Akşam (27 Ağustos 2011), 18 "Medeniyet Yüksek İnsani Değerlerle İnşa Edilebilir”, Akşam (15 Ağustos 2012), 16; 
birisi de adalet duygusu ve rahmet idi. 20 Temmuz 2013 tarihinde Hürriyet Gazetesi’ne yazdığ 1 bir makalede "adaletin insanı yücelten ve insan onurunu besleyen en önemli kaynaklardan birisi olduğunu" etraflıca analiz etmişti. Söz konusu makaleden şu pasaja yer vermek anlamlı olacaktır:

"Adalet, bireysel ve toplumsal planda insanca yaşamanın da ana ilkesidir. Adaleti yaşam biçimine dönüştüremeyen, içselleştiremeyen birey ve toplumların mutlu olmaları pek mümkün değildir. İnsanı yücelten, insan onurunu besleyen en önemli kaynaklardan birisi adalettir. Adaletsizliğin bilinçli olarak uygulanması, ilk bakıșta zulme, haksızlığa uğrayanın onuru ile oynama olarak yorumlanabilir. Allah, insanoğlunu şöyle uyarmaktadır: "Sakın bir topluluğa olan öfkeniz sizin haksızlık yapmanıza yol açmasın. Evet, daima adaletli olun." (Maide, 8). Adaletsizlik, fitrata aykırı davranmaktır, onursuzluktur."31

Hasan Onat, günümüzde şiddete yönelenler ve sorunları şiddetle çözmek isteyenlerin ruh hallerini tahlil ettiği makalesinde, şiddet ve terörün sebebini yaratıcıllğın engellenmesine bağlamış ve bu fikrini şu şekilde açıkladı:

"Yaratıcığın engellenmesi, insanoğlunun birtakım yıkıcı duygulara, hatta şiddet ve teröre yönelmesine yol açabilir. Evrensel yaratma sürecine katkı yapamayanlar, onu önlemeye çalışırlar. Yapabilecekleri ise, yakmak, y1kmak, yok etmek ve öldürmek olur. Küresel boyut kazanan şiddet ve terörün yaratıcılıkla irtibatı iyi

“Özgürlük ve Yaratıcılı", Hürriyet (10 Temmuz 2013), 8; “Adalet: Varoluşun Kurucu İlkesi", Hürriyet (19 Temmuz 2013), 6; "İnsan Onurunu Adalet Yüceltir”, Hürriyet (20 Temmuz 2013), 6; “İslam: İnsan Olma Projesi”, Hürriyet (7 Temmuz 2014), 6;"Allah İnsandan İnsan Olmasin1 İster", Hürriyet (14 Temmuz 2014), 6 ; "Din İstismarını Önlemenin Yolu Din Alanında Doğru Bilgiden Geçer”, Akşam (13 Eylül 2009), 19; “Din Alanında Bilgi Kirliliği Üzerine", Akşam (21 Ağustos 2010), 14; "Adalet Olmadan İnsanlık Olmaz", Akşam (23 Ağustos 2010), 17; "Dini Meseleleri Niçin Doğru Dürüst Tartışamiyoruz?", Akşam (24 Ağustos 2011), 17; "Aklı Etkin Kullanmak/Düşünmek İbadettir”, Hürriyet (12 Temmuz 2013), 6;“İslam'1 Yeniden Düşünmek", Akşam (11 Eylül 2009), 17; "Din Alanında Eleştirel Yaklaşımın Önemi", Akşam (31 Ağustos 2009), 16 ; "Müslümanın Hedefi Zekat Verecek Hale Gelmektir", Akşam (3 Eylül 2010), 1 ; "Din Kimsenin Tekelinde Değildir", Akşam (16 Ağustos 2011), 15; "İslam Ortak Paydası", Akşam (27 Temmuz 2012), 16; "Kadının Olmadığı Yerde Uygarlık Olmaz", Akşam (27 Ağustos 2010), 17 ; "Din ve Siyaset Dilinin Korkudan Arındırılmas1 Gerekir/Korku Yoğunluğu Sizi Korkutmuyor mu?”, Akşam (1 Eylül 2010), 17 ; "Din İnsanı Özgürleştirir", Akşam (26 Ağustos 2009), 19 ; "Din İnsan İçin Vardır”, Akşam (15 Ağustos 2010), 18; "Allah İnsandan İnsan Olmasını İster”, Hürriyet (14 Temmuz 2014), 6 .

31 Hasan Onat, “İnsan Onurunu Adalet Yüceltir”, Hürriyet (20 Temmuz 2013), 6 
irdelenmelidir. Engellenme duygusu sağliklı düşünmeyi, doğru kararlar almayı güçlesstirir. Yaratıcılığını engellendiği şeklindeki algı, bireysel ve toplumsal planda öfke birikmesinin en mühim sebeplerinden biridir."32

Hasan Onat, Bizim Dergah adıyla çıkan aylık dergiye 1993 yılın $58,59,60,61$. sayılarına İslam'ın insana bakıșı ve gençlere İslam'ın nasıl anlatılacağı konusunda yazılar yazdı. Ayrıca ilk sayısı 1997 yılının Haziran'dan itibaren aylık olarak çıkmaya başlayan Çankırı'ya Hasret Gazete'sinde, "Baş Yazı" adı altında ilk sayfada köşe yazıları yazdı. ${ }^{33}$ İlk beş sayısında Türkiye'nin içine sürüklendiği gerilim ortamını ve din olgusunu, Türkiye'de zihniyet sorununu, demokrasi kültürünü ve rejim tartışmalarını, çağdaş eğitim ve Türkiye'nin bazı gerçeklerini, sosyal değişim ve aile konularını analiz etti ve kendi çözüm önerilerini sundu.

Hasan Onat, son yıllarda sosyal medya aracıllğı ile fikirlerini paylaşmaya büyük önem verdi. Entelektüel çevrelere ulaşmak için sosyal medyayı, özellikle Twitter hesabını kullanıyordu. 2014 yılında açtığ Twitter hesabindan 2015-2020 y1lları arasında Türkiye'nin yaşadığ1 sorunlarla ilgili çözüm önerileri, eleştirileri ve yorumlarını konu edinen tweet paylasst. Sayıları 3000'ni aşan tweetlerinin her biri, bir kitap özeti gibiydi. Bunlar, konularına göre tasnif edildiğinde bir kitap olarak yayınlanabilecek muhtevaya sahipti. Vefatından önce 45.000'nin üzerinde takipçisi vard1.

Hasan Onat'ın 04.04.2015 tarihinde paylaştığı ilk tweet'i şöyledir:

"Hayatın anlamının yaratıcılıkta olduğunu fark edemeyenler, yakarak, yıkarak, yok ederek ve öldürerek hayatı anlamlı kılmaya çalışirlar."

32 Hasan Onat, "Allah İnsandan İnsan Olmasını İster", Hürriyet (14 Temmuz 2014), 6.

$33 \mathrm{Bu}$ yazılar tespit edebildiğimiz kadarıyla sırayla şöyledir: Hasan Onat, "Çankırı'lı Olmak-Baş Yaz1-", Çankıri'ya Hasret (2 Mayıs 1997), 1 ve 9; "Türkiye'nin İçine Sürüklendiği Gerilim Ortamı ve Din Olgusu- Baș Yazı-", Çankıri'ya Hasret (2 Haziran 1997), 1 ve 9; "Türkiye'de Zihniyet Sorunu - Baş Yaz1-", Cankiri'ya Hasret (2 Temmuz 1997), 1 ve 9; "Demokrasi Kültürü ve Rejim Tartışmaları Üzerine- Baş Yazı-" Çankırı'ya Hasret (2 Ağustos 1997), 1 ve 9; "Çağdaş Eğitim ve Türkiye'nin Bazı Gerçekleri- Baş Yaz1-", Çankıri'ya Hasret (2 Eylül 1997), 1 ve 9; "Sosyal Değişme ve Aile- Baş Yaz1-", Çankırı'ya Hasret (2 Ekim 1997), 1 ve 9; “Türkiye'nin Gerçekleri ve Din”, Çankıri'ya Hasret (Kasım-Aralık 1997), 1 ve 9; "Türkiye'de Din Alanının Tartışmaya Açılması ve Önemi- Baş Yazı-", Çankıri'ya Hasret (Ocak-Şubat 1998), 1 ve 9; “Değişim`Rüzgarları ve Yeniden Yapılanma”, Çankır'ya Hasret (Temmuz 1998), 1 ve 9. 
Hasan Onat'ın 15.09.2020 tarihinde saat 09:36'da paylaştığı son tweet'i ise şöyledir:

"Maziye mahkum olmaktan kurtulabilmek için; 1) Hayatın geleceğe doğru aktığını, 2) "Geçmiş"in de her daim yeniden inşa edildiğini, 3)Yaratıcı yetilerini yitiren birey toplumları geçmişi kutsallaştırdıklarını, 4) Eskilerin kavgasını sürdürmenin akıl işi olmadiğını bilmek gerekir."

\section{2. İlkeli Bir Yönetici}

Hasan Onat', Anabilim Dalı Başkanlığı, Bölüm Başkanlığı ve Dekanlık görevlerini üstlendi. Ankara İlahiyat'ta 1996 tarihinden itibaren aralıklarla Fakülte Kurulu ve Yönetim Kurulu üyeliği yaptı. Ankara İlahiyatın bilimsel ve kurumsal kimliğini en iyi temsil eden bir akademisyendi. 03.01.1991-26.09.2020 y1llar1 arasında İslam Mezhepleri Tarihi Anabilim Dalı Başkanlığı, 2008-2009 y1lları arasında Temel İslam Bilimleri Bölümü Başkanlığı görevlerini üstlendi.

Hasan Onat'a göre yöneticilik elde edilmesi gerekli bir amaç değil projelerini ve hedeflerini gerçekleştirmek için önemli bir araçtır. Onun hayalinde siyasi kutuplaşmalardan ve grupçuluktan uzak bilimselliğin esas alındığı bir üniversite ve içerisinde bir İlahiyat Fakültesi kurmak düșüncesi vardı. Bunu devlet üniversitesi içerisinde de bașarabileceğini düșünüyordu. $\mathrm{Bu}$ sebeple Gazi Üniversitesine bağlı Çorum İlahiyat Fakültesi için kendisine yapılan dekanlık teklifini geri çevirmedi. Tekliften sonra Gazi Üniversitesi'nin o zamanki rektörü ile görüşerek, dekanlığ üstlenmesi için bazı şartlar koştu. Bunlardan birisi 28 Şubatçıların başörtüsü yasağını ve İlahiyat üzerindeki baskıları sürdürmeyi kendisinden istememesiydi. $\mathrm{Bu}$ görüşmelerden sonra Ankara'daki görevini bırakmadan, belli günlerde Çorum'da görevinin başında olmak şartıyla dekanlık görevini kabul etti. Bundan sonra Yüksek Öğretim Kurulu Başkanlığı'nın 2. 8. 1999 tarihli kararıyla, Gazi Üniversitesi Çorum İlahiyat Fakültesi Dekanlığı'na atandı. 16. 8. 1999 tarihinde Ankara Üniversitesi İlahiyat Fakültesi'ne verdiği dilekçeyle, gerekli işlemlerin yapılmasını istedi ve 16. 8. 1999 tarihinde görevine başladı ve bu görevde üç y1l kald1. 17.08.2002 tarihinde görevinin sona ermesiyle beraber, 19.08.2002 tarihinde Ankara Üniversitesi İlahiyat Fakültesi'ndeki görevine geri döndü. Aslında Hasan Onat, kendi Fakültesi'nde de dekanlık görevinde bulunmayı arzuluyordu; ancak bu göreve bizzat kendisi talip olmak istemedi. Onat, 2008 y1lında Çankırı Karatekin Üniversitesi Rektörlüğü adayları arasında yapılan seçimde ikinci sırada yer almasına rağmen, böyle bir göreve getirilmedi. 
Hasan Onat, Çorum İlahiyat dekanlığındaki başarıları sebebiyle, başarılı bir yönetici olarak tarihe geçti. Çünkü o, yönetim konusunda katılımc1lığa, eleștiriye, birlikte iş yapmaya, kurumsallığa, kişiliklere sayg1 duyulmasına ve kissisel hakların korunmasına önem veren akademisyenlerden biriydi. Sorun çözücü bir yeteneğe sahipti. Dekanlığa atandığında öğretim üyeleriyle yaptığı ilk tanışma toplantısında, bu ilkeyi onlara şöyle ifade etmişti:

"Bana sorunlarla gelmeyiniz. Şayet gelirseniz çözümünü de beraberinde getiriniz."

Hasan Onat'in yönetici olduğu üç yıllık kısa denebilecek bir sürede, akademik kurumsallaşmayı önceledi ve Çorum'da bilimsel kimliği güçlü bir öğretim kadrosu oluşturmaya çalıştı. Ankara İlahiyat'in kurumsal ve bilimsel geleneğini buraya taşımak için çalıştı. Bu sebeple İlahiyatın kadrolaşmasını titizlikle yürüttü ve alınacak kişileri alanın uzmanlarından oluşan bir komisyonun seçmesini istedi. Onat, Çorum İlahiyat'in ileride Çorum'da kurulacak bir üniversitenin kurucu fakültesi olacağı öngörüsüyle hareket etti ve öngörüsü gerçek oldu.

Hasan Onat, katıldığ bilimsel kongre ve sempozyum oturumlarını yönetmede ve televizyon programları yapımı ve yönetiminde de oldukça başarılı idi. Onun bilimsel kişiliği ve yönetici kabiliyeti, tartışmaların farklı boyutlar kazanmasına mani oluyordu.

\section{Etkili ve Başarılı Bir Eğitimci}

Hasan Onat, öğrencisi olduğu Fakülte'de kırk yıla yakın bir süre lisans ve lisansüstü dersler verdi. Lisans düzeyinde, İslam Mezhepleri Tarihi, Çağdaş İslam Akımları, Türkiye'de Dini Akımlar, İslam Dünyasında Dini Akımlar, İslam Bilimlerinde Yöntem ve Sosyal Bilimler Metodolojisi derslerini; Yüksek Lisans'ta Mezhepler Tarihine Giriş, Mezhepler Tarihi Metodolojisi, Alevilik, İslam Mezhepleri Tarihine Giriş ve Araştırma Yöntemleri derslerini; Doktora düzeyinde ise, İslam Mezhepleri Tarihi, Çağdaş İslam Akımları ve Araştırma Yöntemleri derslerini verdi. Yurt içinde 17 Ağustos 1999-16 Ağustos 2002 tarihleri arasında Gazi Üniversitesi Çorum İlahiyat Fakültesi'nde İslam Mezhepleri Tarihi ve Çağdaş İslam Akımları; 2018-2019 Eğitim-Öğretim Y1lı Bahar ve Güz Dönemi'nde Dokuz Eylül Üniversitesi İlahiyat Fakültesi'nde İslam Mezhepleri Tarihi derslerine girdi. Yurt dişında 2010 yılının bahar döneminde bir ay süreyle Kırgızitan Oş Devlet Üniversitesi İlahiyat Fakültesi'nde Mezhepler Tarihi dersi verdi. Ayrıca 17 Ekim 1994-19 Kasım 1994 tarihleri arasinda Roma Gregorian Üniversitesi Misiology Fakültesi'nde misafir öğretim üyesi olarak bulundu ve "An Introduction to Shi'te Islam" (Şiiliğe Giriss) isimli 2 kredilik bir ders 
verdi. Pontificio Istituta Orientale'de ve Pontificio Istituto Di Studi Arabi E D'Islamistica (PISAI)'da Contemporary Islamic Revival in Turkey (Türkiye'de İslâmî Uyanış) konusunda seminerler verdi.

Hasan Onat, Fakülte dişı görevlendirmesiyle, Türkiye ve Orta Doğu Amme İdaresi Enstitüsü'nde 2017-2018 Eğitim Öğretim Y111 Bahar Dönemi'nde “20. Yüzyılda İslam Siyaset Felsefesi II” ve 20172018 Eğitim Öğretim Y1lı Güz Dönemi'nde “20. Yüzyılda İslam Düşüncesinde Siyaset Teorileri" adlı dersler verdi. Ayrıca Milli Savunma Üniversitesi 2019-2020 Eğitim Öğretim Y1lı Güz Dönemi'nde "İslam Tarihi" dersi verdi.

Hasan Onat, öğrenmeye açık bir insand1, kendini sürekli geliştirmeye çalışırdı. Akademisyenler için açılan dil kursları ve eğitim seminerlerine katıld.

Hasan Onat, öğrenci merkezli ve yeni verilere dayalı bir eğitimden yanaydı. Ders vermek, eğitim ve öğretim onun hayat tarzı haline gelmişti. Her derse ilk defa giriyormuş gibi enerjik ve interaktifti. Asistanlık döneminde bir yıl derslere beraber girmiştim. Derslerde hiç oturduğunu görmedim, derslerini hep ayakta anlatırdı. Pandemi dönemine kadar hep böyle devam etti. Tartışmalı geçtiği için derslerin nasıl bittiği anlaşılamazdı. Yıl boyunca bütün derslerine aksatmadan girerdi. Ciddi bir maniası varsa benim girmemi isterdi. Ayrıca Doktora tez konum olan Mürcie konusunu her yıl bana anlattırırdı. 2019 yilında da böyle oldu.

Hasan Onat'in ilme ve ilim ehline ayrı bir saygısı vardı. Yanına gelen her öğrenciyi ilme, akla ve araştırmaya yönlendirirdi. Onun bu teşvikleriyle pek çok kişi akademisyen oldu. Başka bölümlerde aradığını bulamayan ve daha bilimsel bir ortam arayanlar, İslam Mezhepler Tarihi'ni tercih ederdi. Onun için öğretmenler ve öğretim üyeleri, "ebediyete hitap eden" saygın kişilerdi.

Hasan Onat, zeki ve yetenekli öğrencileri lisansta iken akademik hayata yönlendirirdi. Bilim adamı olmaya namzet tecessüs ruhlu öğrencileri lisans döneminde seçer ve onlara çok sayıda kitap okuturdu. Okunan kitapları birlikte tartışmak için özel zaman ayırırd1. Özellikle öğrencilerin özgüven sahibi olmasına, eleştirel yaklaşma ve özgür düşünme yeteneklerinin gelişmesine katkı sağlayacak kitaplardan başlatırdı. Daha sonra özgün konularda onlara lisans tezleri verirdi. Onunla bu macerayı yaşayan her öğrenci, bilim dünyasına ilk adımını atmış olurdu. Onun ilgilendiği pek çok öğrencisi şu anda çeşitli üniversitelerde öğretim üyesi olarak görev yapmaktadır.

Hasan Onat, öğrenci sayısının azlığı dolayısıyla master ve doktora derslerini odasinda yapard1. Her hafta bir konu ile ilgili kitap ve makaleler verirdi. Okunan kitap ve makalelerle ilgili değerlendirmeler 
yazılmasını ve bunların derste sunulup tartışılmasını isterdi. Yazmak ve tartışmak son derece önemliydi. Çünkü bu sayede öğrenciler hem akademik yazımın hem de bilimsel tartıșmaların nasıl yapıldığını öğrenme imkânı buluyordu. Master ve doktora derslerinde vize ve final sinavları yerine araştırma konuları hazırlatırdı. Sinav yaptığında da, hazırladığı sorular ezbere dayalı değil yorum ve düşünceye açık sorular olurdu. Yüksek Lisans ve doktorada sinav yerine geçecek her bir araștırma konusunun, bilimsel araştırma usul ve yöntemine uygun olarak yazılmasını isterdi. Bu sayede kaynaklara dayalı eleştirel araştırma yöntemi öğrenciler tarafından bizzat tecrübe edilmiş olurdu. Özellikle birinci el ve ikinci el kaynakların önemi, kaynak kritiği, fikir-hadise irtibatı ve analitik düşünce konusuna çok önem verirdi. Yüksek lisans ve doktora öğrencilerine sadece Mezhepler tarihinden ders aldırmazdı. Kelam, Tasavvuf, Felsefe, Din Felsefesi, Tefsir, Tarih, Dinler Tarihi gibi başka alanlardan da her dönem bir veya iki ders seçtirirdi. Öğrencinin yüksek lisans ve doktorada çalıșacağı konuları dikkate alarak, bu dersleri seçmelerini isterdi. Her yıl yüksek lisans ve doktora derslerinde okuttuğu ve tartıştığ kitap ve makaleler değişirdi. Derslerde Sosyoloji, Psikoloji, Tarih Felsefesi ve Antropoloji alanlarıyla ilgili alanımıza katkı sağlayacak temel eserlere öğrencileri yönlendirir, geri bildirimlerini de mutlaka isterdi.

Hasan Onat, lisans derslerinde sinavlarda ezbere dayalı sorular yerine analiz yeteneğini ölçebilecek yoruma dayalı, eleștirel yaklaşıma açık sorular sorard1. Öğrencinin ders içi ve ders dışı etkinliklerini değerlendirmeye dâhil ederdi. Özellikle seçmeli derslerde öğrencilere yeni ilgi alanları açmak için araştırmalar verir, sunumlar yaptırırd 1.

\section{Yol Gösterici ve Cesaretlendirici Bir Danışman}

Hasan Onat, Ankara İlahiyat geleneğinde yetişmiş olması ve Ethem Ruhi Fığlalı'nın öğrencisi olması dolayısıyla bilimsel bir araştırmanın aşamalarını çok iyi biliyordu. Danışmanlığını üstlendiği öğrencilerden önce tez konusu olabilecek konular tespit etmelerini isterdi. Tespit edilen üç-dört veya daha fazla konu arasından birisi üzerinde yoğunlaşılır ve bir seçimde bulunulurdu. Belirlenen her bir konunun elenmesi neredeyse bir iki ay sürerdi. Konu belirleme sürecine dersler sırasında bașlanırdı. Daha sonra üzerinde karar kılınan konu seminer olarak alınırdı. Seminerde sorun tespit edilmiş ve ilk kaynak taraması yapılmış olurdu. Sonrasında konu sınırlandırılır ve geniş bir kaynak taraması aşamasına geçilirdi. Ders döneminin sonunda bir öğrenci tez önerisi hazırlayacak aşamaya gelirdi. Bu aşama epeyce uzun sürerdi. En az üç ört defa taslak 
değiştiği olurdu. Her defasında tartışılan ve üzerinde değişiklikler yapılan taslağa bir tarih atılmasını isterdi. Tez konusu için bir taslak olussturduktan sonra kaynak taraması ve bilgi toplamaya başlanmasinı önerirdi. Daha sonra tezin kompoze edilmesi aşamasına geçilirdi. Yazma bittikten sonra birlikte okuma ve düzeltme yapılırd1. Tez, savunulacak hale geldiğinde jüri önüne çıkarılırdi.

Hasan Onat, ilk yüksek lisans tez danışmanlığı ve ilk doktora danışmanlığını benim tezlerimde yapmıştı. Bu süreçte Ethem Ruhi Fığlalı'nın fikrî desteğini ve önerilerini çok önemsiyordu. Savunmaya öncesinde benden doktora tezimi 1994 yılı bahar döneminde Muğla Sitkı Koçman Üniversitesi'nde rektörlük görevinde bulunan Ethem Ruhi Fiğlalı Hocamıza göndermemi istedi. Fiğlalı Hocamı, tezi okuyup beni Muğla'ya çağırdı, ben de bu vesileyle Muğla'ya gittim. Sayın Hocamız, beni Rektörlük makaminda kabul etti ve saat 09:00'dan 13:00'e kadar telefon dahi almadi. Sekreterine telefonlar1 bağlamamasını söyledi. Bu sürede, satır satır okuduğu tezimle ilgili eleştiri, değerlendirme ve katkılarını sundu. Bu görüşme esasen tek kişilik bir tez savunması idi. Benim için bu savunma, jüri huzurundaki savunmamdan daha zor oldu. Sonrasında ilgili yerleri düzelttim ve savunmaya hazır hale getirdim. Fiğlalı Hocam, Hasan Onat Hocam ve Sönmez Kutlu arasındaki bu ilmî geleneğin mahiyetini, Dokuz Eylül İlahiyat Fakültesi'nde birlikte katıldığımız bir panelde "Dede, Oğul ve Torun" olarak kavramsallaştırdı ve aynı masada birlikte yer almaktan gurur duyduğunu heyecan ve coşku dolu ifadelerle belirtti.

Hasan Onat'in yaptırdığı tez çalışmalarının büyük bir kısmı ilk döneme aitti. 31 yüksek lisans ve 21 doktora tezi olmak üzere danışmanlığını yaptığı toplam 52 tezin ${ }^{34}$ bitiş tarihleri dikkate alındığında ve konuları ile tarihi sınırları incelendiğinde İslam Düşüncesi'nin gelişim sürecinin fotoğrafını ortaya koyma hedefinin 3. veya 4. hicri asırlara kadarki kısmını gerçekleștirdiği görülecektir. $\mathrm{O}$, bilimsel çalışmalarda bilimsel zihniyeti, devamlılığı ve birikimliliği çok önemserdi. Tek başına çalışan veya üreten birisi değildi. Ekip çalışmasını çok severdi ve bu konuda iyi bir yönlendirici idi. Yapmak istediklerini doktora tezleri üzerinden projelendirirdi. Onun doktora tez danışmanlığı atölye çalışması niteliğindeydi. Her dönemde 4-5 ya da daha fazla doktora öğrencisi olurdu. Her bir doktora öğrencisi tezini yazdığında, önce bölümdeki doktora öğrencileri okurdu. Sonra ben okurdum, en son olarak ise kendisi okurdu. Bu okuma sürecine herkes katılırdı. Hem öğrenir hem öğretirdi. Yeni fikirlere açıktı. Yeter

34 Tez sahiplerinin isimleri, tez başlığı ve bitiş tarihi bilgilerinin yer aldığı listeler derginin sonunda EK’te verilmektedir. 
ki iddia sahibi iddiasını bilimsel verilerle ve delillerle ispat edebilsin veya savunabilsin. Adaya fikir empozesi yapmazd1 ve tez bitmeden adayın fikir özgürlüğünü baskılamazdı. Önce adayın özgürce düşünmesini ve yazabildiğini yazmasını beklerdi. Eğer aday araştırma süreçlerinde sorunlarla karşılaşırsa onun önünü açar ve onu cesaretlendirirdi. Doktorasını bitirmemiş olsalar dahi, adayları bir başkasıyla tanıştırırken meslektaşımız veya kürsümüzün elemanı olarak tanıtırdı. Danışmanlık yaptığı tezlerde en çok üzerinde durduğu husus, adayın fikirleriydi, yani tezde kendisi olmasıydi. Başkalarının bilgilerine mahkûm olmak veya onun hamallığını yapmak yerine yeni fikirler üretmeyi önemserdi.

15. Kavram Üreten, Kavramlarla Düşünen ve Düşündüren Bir Bilim İnsanı

İnsan, aklı sayesinde "nesneler ve olayların ortak özelliklerini kapsayan ve ortak bir ad altında toplayan genel kavramlar üretebilen" bir varlıktır. Kavramlarla düşünen ve kavramlarla düşündüren bir bilim adamı olan Hasan Onat, ilmî araştırmalarında ve konuşmalarında yeni kavramlar kullanır, eskileri eleştirir veya onları yeniden tanımlardı. O, insanın yaratıcılığının "kavramlaştırma yetisiyle ve kavramlarla düşünmesiyle" birlikte başladığına inanır ve bu fikrini şöyle temellendirir:

"İnsan yaratıcı yetilerle donatılmıştır. İnsanın yaratıcılı̆̆ı, "kavramlaştırma yetisiyle ve kavramlarla düşünmesiyle birlikte başlar. İşte insanın biricikliğinin, özgünlüğünün gerçek anlamı bu gerçeklerde gizlidir." 35

Hasan Onat'a göre, özgün düşünebilmek için kendi kavramlarımızı üretmek veya mevcut kavramları yeniden tanımlamak ve geçmişten bize intikal eden kavramların anlam değişikliklerini, daralmalarını, genisslemelerini ve tamamen farklı anlamlar kazanmış olabileceğini dikkate almak gerekir. Ona göre bugün "insanlık tarihinde derin izler bırakan oluşumların arka planını anlamaya çalışmak" kendi ürettiğimiz kavramlarla mümkündür. Çünkü kavramlar, içerik ve delalet açısından değişmektedir. Geçmişte üretilen kavramlar, farklı kültürel ortamlarda üretildiği için doğru bir şekilde tanımlanamamakta ve anlassılamamaktadır. Bu da sorunların analizinde bilimsel açıdan sağlıklı doğru bilgilere ulaşmamızı engellemektedir. Örneğin Alevilikle ilgili tartışmalarda kullanılan "Şiî, Ca'ferî, Nusayrî, Rafizî, Kızılbaş, Çepni, Tahtacı, Alevi ve Bektaşî kavramları genellikle

35 Hasan Onat, “İnsan Biricik ve Özgün Bir Varlıktır”, Prof. Dr. Hasan Onat (Erişim 02 Haziran 2021). 
birbirine karıştırılmaktadır." 36 Onat, son dönemlerde Arapça'dan ve Farsça'dan çevrilen dinî literatür yoluyla Türkçe'ye yerleşmeye başlayan kavramları, din anlayışımız üzerinde tahribata yol açan ve bize ait olmayan ödünç kavramlar olarak nitelendirmektedir. ${ }^{37}$

Hasan Onat, İslam düşüncesi ve özellikle İslam Mezhepleri Tarihi alanında belli dönemin kültürel, siyasi ve toplumsal şartlarının ürünü olan kavramlara karşı eleștirel yaklaștı ve bu kavramlarda tarihsel süreç içerisinde yaşanan anlam, zaman ve mekân kaymalarını tespit etmeye çalıştı. O, "kavramların, bağlamları, içerikleri ve irtibatlı oldukları zaman ve mekân hesaba katılmaksızın rastgele kullanılmasına" karşı çıktı. O, kendi alanıyla ilgili "çekirdek İslam", "kurumsallaşmış İslam", "mezhepler üstü düşünme", "mezheplerüstü", "İslam ortak paydası" ve "kök değerler" başta olmak üzere pek çok yeni kavramsallaştırmalar yaptı. Esasen bu kavramların her biri, üzerinde müstakil olarak durmayı gerektirecek ölçüde yüklü muhtevalara sahiptir.

Hasan Onat, klasik kaynaklarda daha önce tanımlananları da yeniden tanımlama yoluna gitti. Örneğin mezhepleri "dinin anlaşılma biçimleri ile ilgili tezâhürler"38 olarak gören Onat, mezhep kavramını anlayış farklılığ1, kurumsallaşma ve beşerî oluşum boyutunu dikkate alarak şu şekilde yeniden tanımladı:

"Mezhepler, din anlayışındaki farklılaşmaların kurumsallaşması sonucu ortaya çıkan beşeri oluşumlardır." 39

Hasan Onat, bir mütefekkir sorumluluğuyla sadece mezheplerle ilgili kavramları değil İslam düşüncesinin diğer alanlarında kullanılan bazı kavramlara dair geçmişte üretilen algıları da eleştirdi ve onları yeniden tanımlamaya çalıştı. Bunların başında Kur'an'da

${ }^{36}$ Hasan Onat, "Değişim Sürecinde Alevilik", Prof. Dr. Hasan Onat (Erişim 01 Haziran 2021).

37 Hasan Onat, "Türkiye'de Din ve Laiklik", Prof. Dr. Hasan Onat (Erișim 01 Haziran 2021).

38 Hasan Onat, "Mezhep Kavramı ve Mezheplerin Doğuş Sebepleri", Prof. Dr. Hasan Onat (Erişim 01 Haziran 2021); Sorularla Mezhepler Tarihi (Ankara: Yayınlanmamış nüsha, 2016), 10.

39 Hasan Onat, "Mezhep Kavramı ve Mezheplerin Doğuss Sebepleri”, Oş İahiyat Fakültesi Dergisi (2005), 7 (7-23); Krş. E. Ruhi Fiğlalı, Günümüz İslam Mezhepleri (İzmir: İzmir İlahiyat Vakfı, 2008), 15-16. 
çok sık kullanılan "salih amel", "münafik"40, "cihad" 41 ve benzeri kavramlar gelmektedir. Örneğin "salih amel"i, dinî-ahlakî bir kavram olması yanı sıra iktisat ahlakının temel kavramlarından birisi olarak kabul etti. Onun gelenekte farklı algilanan ve tanımlanan "salih amel" kavramina ilisskin analizlerine ve bu kavrama dair yeni bir tanım denemesine yer vermek anlamlı olacaktır:

"Bu doğrultuda düşündüğümüzde, "salih amel/iyi iş" kavramını yeniden gözden geçirmemiz gerektiğini hemen fark edebiliriz. Yaygın alg1 biçiminde, salih amel denildiğinde akla hemen, namaz, oruç gibi ibadetler gelmektedir. Bunlar temel İslami ibadetlerdir. Müslüman insanın hayatında, bunların yeri, tıpkı nefes almak, su içmek gibi, temel ihtiyaçlar kategorisindedir. Bunlar, insana, kendi varlığının farkında olma imkânı sağladığı gibi, zaman bilinci de kazandırır. Namaz, insanı kötülüklerden alıkoyar. Oruç, insanın Allah'a bilinçli sayg1 duymasını sağlar. Hacc, zaman ve tarih bilincini uyandırır. Zekât, insanı malın mülkün esiri olmaktan kurtarır. Kısaca temel İslami ibadetler, insanın aklını terbiye ederek doğru düşünmesini kolaylaştırır. Doğru düşünen insan neyi nasıl yapacağını, enerjisini nasıl verimli kullanacağını iyi bilir. Hayatın akışı içinde bir tür işaret taşları gibi olan bu ibadetler, insanın yaratıcılığını verimli kullanmasını da mümkün kılar. O zaman, salih amelin, doğrudan insanın yaratıcılığının tezahürü olan faaliyetler olduğunu söyleyebiliriz. Daha açık bir ifadeyle, salih amel, insanın yeni bir şey ortaya koyabilmek, bir şeyler üretebilmek için yaptığı faaliyetlerin tamamı anlamına gelmektedir." 42

\section{Metaforlarla Düşünen ve Düşündüren Bir Bilim İnsanı}

Hasan Onat, metaforlar kullanarak düşüncelerin kolay anlaşılmasını sağlamak konusunda en başarılı bilim adamlarından birisiydi. O, kendi alanı ile ilgili din, mezhep, bilim gibi zor konuların kolay anlaşılmasını sağlamak için kitaplarında, makalelerinde,

40 "Münafık" sözcüğü, Arapçada çift giriş çıkışı olan tarla faresi yuvası anlamına gelen "nefak"tan türemiștir; ilkesiz davranan, çıkarlarına göre hareket eden, olduğundan başka türlü görünen, "ikiyüzlü" insan tipini ifade için kullanılan bir kavramdır." Hasan Onat, "Konuştuğu Zaman Yalan Söyler", Hürriyet (24 Temmuz 2014), 8.

41 "Cihat, "Allah uğruna savaşmak" şeklinde, herkesin içeriğini istediği gibi doldurabileceği bir hale de dönüştürülebilir. İslam'a saldırmak isteyenler de, onu, din adına yapılan savaş olarak anlar ve anlatırlar. Oysa, cihat, İslam'ın en kapsamlı kurucu ilkelerinden birisi olan "adalet"in, hayatın bütün alanlarında hakim kılınması için bilinçli çaba harcamaktır." Hasan Onat, "İslam'da Asıl Olan Hayat ve Barıștır", Hürriyet (21 Temmuz 2014), 6.

42 Hasan Onat, "Hayatın Anlamı İnsanın Yaratıcı Yetilerinde Gizlidir/Başarmak Hayatın Anlamını Yakalamaktır", Akşam (27 Ağustos 2011), 18. 
sunumlarında, radyo ve televizyon konuşmalarında ve derslerde tabiat ve evrenden seçtiği herkesin anlayacağı metaforlar kullandi. Onun bu konuda özellikle Kur'an'ın metafor kullanımından etkilendiği söylenebilir. Çünkü bazen Kur'an'da geçen bir metaforu alıp onun üzerinden muhataplarına konuyu daha anlaşılır kılmaya çalıştığ1 görülür. Örneğin zamanı gelmiş fikirleri tohuma benzetir ve bunu Kur'an'da güzel söz için kullanılan "Kökü sapasağlam, dalları göğe doğru uzanan güzel-diri bir ağaç" metaforuyla birleştirerek şöyle açıklar:

"Zamanı gelmiş fikirler, filizlenmek için toprağa düşmeyi bekleyen tohumlara benzerler; yeter ki, toprağ ${ }_{1}$ bulsunlar; hemen kök salar, filiz verir ve yürür giderler. Toprak hiçbir zaman tohumu inkar etmez. Zamanı gelmiş fikir, tohumun çatlamaya, filizlenmeye en uygun olan toprağa düşmesi anlamına gelmektedir. Sanki toprak, kucağını açmıs tohumu beklemektedir. Tohum da, sanki toprağın kendisini beklediğinin farkındadır. Eskiler, "dil tohum atar" demişler. Doğrusu güzel söylemişler. Kur'an'da "güzel/doğru" sözle ilgili şöyle bir benzetme yer alır: "Allah'ın, güzel-doğru bir söz için nasıl bir misal verdiğini görmüyor musunuz? Kökü sapasağlam, dalları göğe doğru uzanan güzel-diri bir ağaç gibidir o; Rabbinin izniyle her mevsim meyvesini verip durur."43

Hasan Onat'ın İslam Mezhepleri Tarihi ve Çağdaş İslam Akımları alanında tabiat ve evrenden seçtiği ve en çok kullandığı metaforların başında "nehir", "tohum/meşe palamutu", "arı ve bal" ve "ağaç ve dalları" gibi metaforlar gelmektedir. O, İslam düşüncesinde fikri zümreleşmelerin oluşum süreçlerini ve geçirdikleri istihaleleri anlatmak için "nehir"; mezhep ve akımların beslendiği kaynakları, değişim-dönüşümleri ve fikri kurumsallaşmaları açıklayabilmek için "tohum veya meşe palamudu"; bilimsel bilgi ile malumatı ayırmak için arının pek çok çiçekten alarak yaptığı "bal" ve "kültür ve medeniyet kavramları"nı anlatabilmek için "ağaç ve dalları"44 metaforunu kullandı. Biz bunların ayrıntısına girmeyeceğiz. Sadece

43 Hasan Onat, "Doğru/güzel Söz Sürekli Meyve Veren Ağaca Benzer”, Prof. Dr. Hasan Onat (Erişim 01 Haziran 2021). "Nehir" metaforunun İslam'in ilk Müslümanlardan bugüne kadar farklı şekillerde anlaşılması ve yaşanmasını anlatmak için kullanılması ile ilgili bkz.: Hasan Onat, "İslâm'ı Anlamada Yöntem Sorunları", Gelenek ve Modernite Arasinda İslam Yorumlan, ed. Murat Akın, Hasan Cansız, Necmett.n Erbakan Üni. Yayınları/ISAV Yayınları, Konya 2018, 46.

44 "Kültür", "medeniyet" gibi kavramları anlamaya çalışırken, onların, tıpkı bir ağacın kökleri ve dalları gibi geçmişe ve geleceğe doğru çift yönlü, dinamik bir yap1 olarak inşa edildiğini ve anlaşıldığını belirtmekte fayda vardır." (Hasan Onat, "Yeni Bir İslam Medeniyeti İçin Maturidi ve Maturidiliğin Önemi", Prof. Dr. Hasan Onat (Erişim 01 Haziran 2021). 
toplumsal değişimi ve mezheplerin süreç içerisindeki değişimlerini anlatmak için kullandığı "nehir" metaforu ile aşağıdaki analizlerini paylaşmak yerinde olacaktır:

“'Oluş' halindeki bireylerden oluşan toplum da, doğal olarak sürekli değissen bir toplum olacaktır. Tıpkı akıp giden nehirler gibi, toplum da sürekli değişmektedir. Buna bağlı olarak, insanî olan her şey de, bu değişimden hissesine düşen payı olmaktadır. İnsanın ürettiği kültür ve medeniyet değişmektedir; siyasal yap1 değişmektedir; değerler alanı bile değişmektedir. Ancak, değişimin farkedilmesi, sürecin çok yavaş, ya da çok hızlı işlediği dönemlerde, bir hayli güçleşmektedir. Din olgusu, çift yönlü olarak bu değişim sürecinin içindedir. Hem değişim sürecini etkilemekte, hatta zaman zaman onun istikametini belirlemektedir; hem de, değişimden etkilenmektedir." 45

\section{Müfredat Çalışmalarında ve İlahiyat Programlarının Geliștirilmesinde Donanımlı ve Tecrübeli Bir Alan Uzmanı}

Hasan Onat, 1980 sonrası ilkokul, ortaokul ve lisede zorunlu hale getirilen Din Kültürü Ahlak Bilgisi dersinin 1998-2003 tarihleri arasında Din Öğretimi Genel Müdürlüğü öncülüğünde yürütülen 4., 5., 6., 7. ve 8. sinıflarının müfredatının yenilenmesine yönelik çalışmalarda;46 1998 yılında başlatılan İmam Hatip Liseleri'nin programlarının yenilenmesi çalışmalarında ve 18.06.1991 tarihinde Fakülte'nin müfredat programını yeniden hazırlamak üzere kurulan komisyonda ve 1997 yılında yapılan İlahiyat programlarının yeniden yapılandırılması çalışmalarında yer aldı. Ankara İlahiyat'ta oluşturulan komisyonun hazırladığı programın Fakülte Kurulu'nda görüşülmesinde, komisyon sözcüsü idi ve programın son şeklini almasında önemli katkılarda bulundu. Ayrıca Anadolu Üniversitesi Açık Öğretim Fakültesi'nin 11 Aralık 1997'de uygulamaya konulan ve Ankara Üniversitesi İlahiyat Fakültesi tarafından yürütülen İlahiyat Ön lisans Programlarının hazırlanmasında ve koordinasyonunda görev ald1.

Hasan Onat, ilkokuldan yükseköğretime kadar eğitim kurumlarında uygulanan din öğretimi ve eğitimi programlarının değiştirilmesinin ve yeniden yapılandırılmasının gerekliliğini

\footnotetext{
45 Hasan Onat, “Türkiye'de Din Anlayışı”, Prof. Dr. Hasan Onat (Erişim 01 Haziran 2021). Başka bir makalede "nehir" metaforunu İslam'in ilk dönemden bugüne değişimini anlatmak için kullanmıştır. Bkz.. Hasan Onat, "İslâm'1 Anlamada Yöntem Sorunları", Gelenek ve Modernite Arasında İslam Yorumlan, ed. Murat Akın vd. (Konya: Necmetten Erbakan Üniversitesi Yayınları/ISAV Yayınları, 2018), 46.

46 Milli Eğitim Bakanlığı Tebliğler Dergisi, 63/2517 (Ekim 2000).
} 
savundu. O, sadece bu konuda gerçekleştirilen çalışmalara katılmakla kalmadi kitaplarında ve makalelerinde, ulusal ve uluslararası sempozyumlarda konuyla ilgili görüşlerini paylașarak önemli açılımlar sağladı. O, doğru bilgiye dayalı ve Kur'an merkezli ve çağdaş bir yaklaşımla verilen nitelikli bir din eğitim ve öğretiminden yanaydı. ${ }^{47}$ Siyasi ve itikadi oluşumlar, fikıh mezhepleri ve tasavvufi oluşumlar, İslam kültürünün bir parçası olarak ilk defa onun önerileriyle İlköğretim ve Ortaöğretim Din Kültürü Ahlak Bilgisi ders programlarına dahil edildi. Alevilik-Bektaşilik de bu çerçevede müfredata girmiş oldu.

Hasan Onat'in, programa katkısı olanların ve dönemin Fakülte dekanı Mustafa Sait Yazıcıŏlu'nun sözlü ve yazılı beyanlarında açıkça dile getirildiği üzere İlahiyat programlarının yenilenmesi yönündeki çalışmaları, siyasi iradenin veya bazı çevrelerin zorlaması ile yaptırılmadi. Zaten programı hazırlayan komisyon üyeleri, program geliştirmenin bir uzmanlık işi olduğunu, belli bir süreçte gerçekleştirilmesi ve "bir takım siyasi veya ideolojik saiklerle yapılacak her türlü müdahaleden uzak olması" gerektiğinin farkındaydılar. Hasan Onat, yapılan eleştirilere cevap olarak programın hangi hedefe binaen hazırlandığını şöyle açıkladı:

“İlahiyat lisans programı Kur'an'1 referans alan, kültürel mirası değerlendirebilen, yaşanan hayatı yorumlayabilen ve problemlere çözüm üretebilen İlahiyatçılar yetiştirme hedefine yönelik olarak hazırlanmıştır." 48

47 Onun din eğitimi ve programlarıyla ilgili görüşleri hakkında geniş bilgi için bkz.: Hasan Onat, Türkiye'de Din Anlayışında Değişim Süreci (İstanbul: Endülüs Yayınevi, 2018),110-115, 129-143; "Din Alanında Doğru Bilgi Sahibi Olmanın Gerekliliği ve Din Kültürü ve Ahlâk Bilgisi Dersleri”, Eğitime Bakış 1/4 (Ekim, Kasım, Aralık 2005),15-20; "İlahiyat Fakültesinde Program Tartışmaları Üzerine”, Türkiye'de Illahiyat Fakültelerinin Konumu ve Dini Bilginin Niteliği, ed. Mahmut Ay vd. (Ankara: A.Ü. İlahiyat Fakültesi Yayınları, 2016), 309-318; "Din Alanında Yeniden Yapılanma U“zerine", Din Öğretiminde Yeni Yaklas,ımlar, ed. Mualla Selçuk (Ankara: MEB Yayınları, 2000), 97-107; "Alevilik-Bektas,ilik (Din Ku"ltu"ru" Ahlak Bilgisi Dersleri ve Diyanet)" Alevilik Bektaşilik Türk Yurdu Yazıları, ed. Erdal Aksoy (Tu"rk Yurdu Yayınları, 2019), 73-96; "Din Eğitiminde İnsan Hakları ve Demokrasi”, Öğretmen Adaylar ve Öğretmenler Ic, in İnsan Hakları ve Demokrasi Eğitimi, ed. Refik Turan (Ankara: Pegem Kitabevi, 2019), 249-274; “Nic,in Din Egitimi?”, Türkiye'de Din Anlayışında Değişim Süreci (İstanbul: Endülüs Yayınevi, 2018) kitabı içerisinde, 129-143; "Eğitim ve Özgürlük Üzerine", Diyanet Aylık Dergi 153(Eylül 2003), 14-18.

48 Hasan Onat, "İlahiyat Fakültesinde Program Tartışmaları Üzerine”, Türkiye'de İahiyat Fakültelerinin Konumu ve Dini Bilginin Niteliği, 310. 
Din Kültürü Ahlak Bilgisi programları ve İlahiyat programlarının hazırlanış süreçlerinden habersiz olan bazı çevreler, bu çalışmaların 28 Şubat sürecine ve hemen sonrasına denk gelmesini ileri sürerek, özellikle 1997 yılında hazırlanan "(İlahiyat) programin 28 Şubat ile irtibatlandırılarak dayatmacı bir perspektifle hazırlandığını" dillendirmektedir. Hasan Onat, bunlara karşı İlahiyat eğitimi ile ilgili Ankara İlahiyat'ta düzenlenen bir sempozyuma sunduğu tebliğde, "Bu iddia işin hakikatine aykırı olduğu gibi, aynı zamanda programda emeği geçenlere yönelik ciddi bir haksızlıktır ve gerçeği yansıtmamaktadır." ${ }^{49}$ diyerek sürecin başlangıcı hakkında şu bilgileri verdi:

“1997-1998 eğitim-öğretim y1lından itibaren yürürlüğe konulan program Ankara Üniversitesi İlahiyat Fakültesi öğretim üyelerinin hissettikleri ihtiyaca binaen kendiliğinden oluşan program yenileme gereksinimi dikkate alınarak hazırlanmıştır. Ankara Üniversitesi İlahiyat Fakültesi öğretim üyelerinin birikiminin ve tecrübelerinin ürünü olan bu program sadece Ankara Üniversitesi İlahiyat Fakültesi'nde uygulanmak üzere hazırlanmış ve YÖK'e önerilmiştir. Yüksek Ögrretim Kurulu ise söz konusu program önerisini tüm ilahiyat fakültelerine şamil kılmıştır."50

$\mathrm{Bu}$ program yenilenmesi, Ankara İlahiyat'ta kuruluşundan beri yapılan program geliştirmesi çalışmalarının bir aşamasını temsil eder. İlahiyat akademik eğitimi ile mesleki-öğretmenlik eğitiminin ayrılması aslında önemli bir başarı idi. Sorun Akademik İlahiyat'tan Arapça hazırlık sınıfının kaldırılması ve Arapça'nın 4 yıla yayılması sorunu idi. Ders programlarında temel alanla ilgili "zorunlu", ilgi alanları oluşturmak için "seçmeli" derslerin konulması oldukça önemli bir yenilikti. Ancak bu programlar, Onat'ın da değişik vesilelerle ifade ettiği gibi, takip edilerek eksiklikleri giderilemedi ve geliştirilmeye devam edilemedi.

18. Haysiyet, Adalet ve Merhamete Dayalı Yeni Bir İslam Medeniyeti İnşa Projesi

Hasan Onat, 2015 yılında Kazakistan'da düzenlenen uluslararas1 bir sempozyumda, "Yeni Bir İslam Medeniyetinin İnşası İçin Mâturîdî ve Maturidiliğin Önemi" ${ }^{1}$ adlı bir tebliğ sunarak, daha önce farklı

\footnotetext{
49 Hasan Onat, "İlahiyat Fakültesinde Program Tartışmaları Üzerine”, Türkiye'de İlahiyat Fakültelerinin Konumu ve Dini Bilginin Niteliği, 309.

${ }^{50}$ Hasan Onat, "İlahiyat Fakültesinde Program Tartışmaları Üzerine”, Türkiye'de İlahiyat Fakültelerinin Konumu ve Dini Bilginin Niteliği, 311.

${ }^{51}$ Hasan Onat, "Yeni Bir İslam Medeniyetinin İnşası İçin Maturdi ve Maturidiliğin Önemi”, Uluslararası Maturidilik Sempozyumu (Dünü, Bugünü ve Gelecegü),ed.
} 
şekillerde ifade ettiği bir fikri, "haysiyet, adalet ve merhamet dayalı ve insanlığın fitratına uygun yeni bir İslam medeniyetin inşa edilmesi" şeklinde sistematik hale getirerek bu toplantıda tartışmaya açtı. Ona göre, bunu başarabilmek için önce, ilahiyat alanında ve dinî bilimlerde yeni bir bilim anlayıssının ve bilgi kuramının oluşturulmasına ihtiyaç vardı. Çünkü medeniyetin yeniden inşası, “İslam'in, yani Kur'an'in kurucu ilkeleri 1şığında yeniden anlaşılmasına bağlıdır. Bu, bir ihtiyaç olmaktan öte, bir zorunluluk olarak anlasslmalıdır." Yeni bir medeniyet tasavvuru ve tartışmaları için Mâturîdî'nin, özellikle bilgi, özgürlük ve din anlayışı hakkındaki düşünceleri ideal bir başlangıç noktası olacaktır. O, bu tezini geniş bir makaleye dönüştürerek yeni bir medeniyetin inşasında gerekli olan kurucu fikirlerin İmam Mâturîdînnin düşünce sisteminden hareketle tespit etmeye ve tartışmaya çalıştı.

Hasan Onat, bu uzun tebliğinde haysiyet, adalet ve merhamet dayalı yeni bir medeniyetin inşa edilmesi görüşünü şu şekilde gerekçelendirdi:

"Temel hak ve özgürlükler, insan hakları gibi konulardaki sık duyulan söylemlere rağmen, insanoğlu hiç bu kadar haysiyete özlem duymamışt. Küresel şiddet ve terör, insan onurunu yerle bir etmektedir. Küresel anlam krizi, insanı insan yapan bütün yüksek değerleri anlamsız hale getirmektedir. İnsan olarak varlığımızı sürdürebilmemiz haysiyetimize yeniden kavussmamiza, adalet ve merhameti hayat tarzına dönüştürmemize bağlıdır. ... İnsanlığın insanca yaşayabilmesi için yeniden yüksek bir insani bilinç seferberliğine, yeniden insanlaşma sürecine ihtiyaç vardır. "Din"in desteğini almaksızın bunun gerçekleştirilebilmesi pek mümkün görünmemektedir. Bu bağlamda, İslam'ın insan onurunu yücelten ve medeniyete vücut veren kurucu kök ilkeleri, Müslümanların onca nesneleşmişliğine rağmen hala diridir ve tüm insanlık için son bir umut ışığı niteliği taşımaktadır. Bu tespitler, bütün dünyanın Müslüman olması gibi bir temenniyi içinde barındırmamaktadır. Amacımız, hiç olmazsa dünyanın bazı bölgelerinde, insan olma bilincini diri tutacak, tüm insanlara "insan olma"nın, insanın en önemli sorumluluğu olduğunu hatırlatacak, umutsuzluğun bataklığında yok olmanın anlamsız olduğunu gösterecek birtakım izlerin, işaretlerin olabileceğini göstermektir. Bunun için de yeni bir

So"nmez Kutlu (Ankara: Ahmet Yesevi Üniversitesi Yayınları, 2018), 677-701. Daha sonra bu tebliğini geliştirerek kendi web sayfasında aynı adla yayınlamıştır. Bkz.: Hasan Onat, "Yeni Bir İslam Medeniyetinin İnşası İçin Maturidi ve Maturidiliğin Önemi”, Prof. Dr. Hasan Onat (03 Haziran 2021). 
medeniyet hamlesinin zorunlu olduğunu düşünmekteyiz. Medeniyeti ancak özgürlük bilinci yüksek toplumlar kurabilmektedir."52

Hasan Onat, ileri sürdüğü bu mefkuresini farklı açılardan tartışarak bu "yeni İslam Medeniyeti”nin aktörlerinin Türkler olacağı neticesine vard1:

"Kurulacak yeni medeniyetin dinî boyutunda Mâturîdî, felsefi boyutunda Fârâbî-İbn Sîna ve bilimsel boyutunda Bîrûnî" esas alınabilir. Bu medeniyetin mimarları, Türkler olacaktır. Kurulacak medeniyet ise haysiyet, adalet ve merhamet medeniyeti olarak tanımlanacaktır." 53

19. İslam Bilimlerinde Yeni Bir Bilim Paradigması: Kök Bilim Paradigmas1

Hasan Onat denilince, onunla özlü bir söz haline gelen "akıl, din ve bilim" üçlüsü anlaşılırdı. Her yazısında ve konuşmasında bu üçünü birlikte anardı ve bu üçü arasında onun zihninde tam bir uyum vardı. Hatta o, bu bilimselliğini yeni bir bilim paradigmas olarak piramitle sembolleștirdi. Her bir bilim alanı ve o alanla ilgili uzmanlar için ortak bir bilimsellikten bahsediyordu. Daha sonra tabii bilimler ve sosyal bilimlerin kendi alanlarına ait bilimsellikten, daha sonra Sosyal bilimler içerisinde İlahiyat ve din bilimleri, onların altında İslam bilimleri ve onun altında her bir anabilim dalının kendine özgün bilimsel yöntem ve yaklaşımı, en tepeye ise her bir bilim adamının kendi çabasıyla oluşturduğu bilimsel yaklaşımını koyuyordu.

Hasan Onat'a göre, yeni bir bilim paradigmasının başkaları tarafindan oluşturulmasını beklemek ve bunun da İslam bilimleri alanına taşınmasını istemek boşuna zaman kaybıdır. Buna hem Müslümanların hem de insanlığın acilen ihtiyacı vardır. Mevcut bilimsel yaklaşımlardan ve "onun özündeki kök bilim paradigmasını merkeze alarak, bilimsel yöntemin ve bilimsel bilginin genel özellikleri çerçevesinde, Sosyal Bilimler şemsiyesi altında bilimsel faaliyetleri sürdürmek"ten başka çare yoktur. Ancak bu yolla "hem yeni bilim paradigmasının oluşmasına katkı sağlanmış olur; hem bu birikimin ve bilimsel anlayışının İslam geleneğindeki bilim kök hücreleri ile yeniden buluşmasına imkan hazırlanmış" olur. İlahiyat Fakülteleri,

${ }^{52}$ Hasan Onat, "Yeni Bir İslam Medeniyetinin İnşası İçin Maturdi ve Maturidiliğin Önemi", Prof. Dr. Hasan Onat (03 Haziran 2021).

53 Onat, "Yeni Bir İslam Medeniyetinin İnşası İçin Maturidi ve Maturidiliğin Önemi", 700. 
Sosyal Bilimler şemsiyesi altında din alanında bilimsel bilgiyi üretmek için kuruldu.

Hasan Onat, Mezhepler Tarihi örneklemi üzerinden İslam bilimlerinin "kök bilim paradigmasını esas alan" ve pramit şeklinde tanımladığı beş kademeli bir yöntem anlayışla bilimsel bilgi üretmeyi şöyle açıkladı:

"İslam Bilimleri, Sosyal Bilimler şemsiyesi altında yer alacakları için, beş kademeden oluşan, en üstte de bilim adamının kişisel anlayışı ile taçlanan bir yöntemle çalışılacaktır.

1. Kademe: Bütün bilimlerde ortak olan genel bilimsel yöntem veya kök bilim paradigması

2. Kademe: Sosyal Bilimler'in yapısal özellikleri ile örülen, "açıklayıcı anlama"yı da içeren Sosyal Bilim Yöntemi;

3. Kademe: İslam Bilimleri Yöntemi;

4. Kademe: İslam Bilimleri içindeki uzmanlık alanlarının kendine özgü niteliklerini öne çıkartan İhtisas Alanı Yöntemi

5. Kademe: Bilim adamının yöntem anlayışının özgün nitelikleri veya bilim adamının kişisel anlayışı

$\mathrm{Bu}$ piramit bize, İlahiyat Bilimlerinde ihtisaslaşmanın bir derinleşmeden çok bir yükselme olması gerektiğini de göstermektedir. Bu hem yöntem hem de alan olarak yükselmedir. Söz gelişi İslam Mezhepleri Tarihi alanında çalışan bir insan, sağlıklı bir bilimsel bilgi birikimine sahip olabilmek için, Temel İslam Bilimlerinin oluşturduğu bir zemin üzerinde, Kelam'ın, İslam Tarihi'nin ve İslam Felsefesi'nin desteğini de alarak, Mezhepler Tarihi çizgisinde yükselmek durumundadır. Sosyal Bilimler şemsiyesi İlahiyatçıya, Felsefe-Sosyoloji-Psikoloji-Antropoloji gibi alanların yöntem desteğini kolayca kullanma imkanı sağlayacaktır. Ayrıca, İlahiyat alanında üretilenlerin Sosyal Bilimler kanalıyla Bilim ortak havuzuna taşınması da mümkün olacaktır."54

54 Hasan Onat, "Bilgi, Bilim ve Yöntem", Islam Bilimlerinde Yöntem, Editör: Halis Albayrak, Ankara Üniversitesi Uzaktan Eğitim Yayınları (Ankuzem), Ankara 2006, 7-24; Hasan Onat'ın bilim ve yeni bir bilim yöntemi ile ilgili diğer makaleleri için bkz.: "Dinî Yayınlarda Bilimsellik Sorunu (Çağdaş ve İslâmî Bilimler Açısından)", Türkiye I. Dinî Yayınlar Kongresi (31 Ekim- 02 Kasım 2003), Diyanet İşleri Başkanlığı Yayınları, Ankara, 2004, 161-168; "Islam Bilimleri ve Yöntemi Açısından Tarihin Anlam ve O"nemi, Kur an ve Islami İimlerin Anlaşılmasında Tarihin Önemi, Editör: M. Mahfuz Söylemez, Ankara Okulu Yay., Ankara, 2013, 13-68; "İslâm'1 Anlamada Yöntem Sorunları", Gelenek ve Modernite Arasinda İslam Yorumlar (6-7 Mayıs 2016), Yayın: Necmettin Erbakan Üniversitesi; İslami İlimler Araştırma Vakfı, Konya, 2017, 45-69. 
Hasan Onat, aklındaki bilim anlayışını ve "kök bilim paradigması"nı hayata geçirmenin yollarını aradı. Bunun için Maturidi Yesevi Otağı Derneği bașkanı Ali İhsan Kılıç ile birlikte uluslararası bir üniversitenin kurulması projesi üzerinde çalışıyordu. $\mathrm{Bu}$ konuda birkaç toplantı yapıldı. Projeye göre, bir ayağı Özbekistan'da bir ayağı Ankara'da olacak bir üniversite kurulacaktı. Ama gerçekleştirmeye ömrü vefa etmedi.

\section{Hasan Onat'in Vefatı}

Hasan Onat Hocam ile, hastalandığ1 süreçte 23.09.2020 tarihinde bir defa sesli telefonla görüştüm. Daha sonra "yormamak için" mesaj yazarak haberleştim. Son iki gündeki yazışmalarımızın sonuncusunu aktararak makaleyi bitirmek istiyorum:

[08:32, 25.09.2020] Hasan Onat: "Sönmez hoca teşekkür ediyorum. Hastahanedeyim. Telefonla da olsa konussmak beni zorluyor. Bugün kafamın yeniden çalışmaya başladığını farkettim; mutlu oldum. İştah açılmaya başladı Çok şükür iyileşiyorum..."

[09:30, 25.09.2020] Sönmez Kutlu: Sayın Hocam,

"Bayağ1 endișelendim. Mesaja cevap alamayınca. Allah’a şükür. Allah șifa versin. En kısa zamanda sağlığınıza kavuşmanız için duacıyız. İnsanlığın sizlere ihtiyacı var.

Selam ve saygilar..."

Sevgili annesi, Hasan Onat'in çok çalışması ve yorulmasına dayanamayarak birgün ona; "Devirmediğin yaprak, basmadığın toprak kalmad1." diyerek dinlenmesini istemiş o da annesine şu cevabı vermişti: "Ana! Yapılacak daha çok iş var." Hasan Onat, gerçekleştirmek istediği pek çok projesini hayata geçiremeden COVID-19 sebebiyle 26.09.2020 tarihinde Cumartesi günü akşam saatlerinde rahmet-i Rahman'a kavuştu. Doğum yeri olan Eldivan'da ailesi, sevenleri ve öğrencileri tarafından ebedi istirahatgahına uğurlandi.

Prof. Dr. İsmail Yakıt, Hasan Onat'n vefat tarihi için şu notu düştü:

Araștırmakla geçti hayatının her anı

Geldi iki zat söyledi Yakut'a tarihi: 
"El-Vâsi', dâhil-i cennet eyleye Hasan'ı"

$1440+2: 1442$

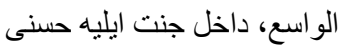

\section{KAYNAKÇA}

Akdoğan, Bayram. "Prof. Dr. Hasan Onat Hoca'mın Bir Güftesini Bestelememle İlgili Bir Hatıram”. Türk Yurdu 399 (Kasım 2020), 110-111.

Akkoyunlu, İsmail. "İslam Mezhepleri Tarihçisi Prof. Dr. Hasan Onat Hatıratı (1957-2020)". ATEBE: Dinî Araştırmalar Dergisi 4 (Aralik 2020), 155-165.

Akoğlu, Muharrem. "Bir Mütefekkir'in Ardından Prof. Dr. Hasan Onat”. Türkiye Yeni Ufuklar Dergisi (Aralık 2020), 79-83.

Albayrak, Halis. "Bir Fikir ve Bilim Adamı Olarak Hasan Onat Paneli". Türk Ocağı TV. 20 Kasım 2020, https://www.youtube.com/ watch?v=GrZ7qpvu4zE\&t=1358s, 19:00-22:40.

Aydınlı, Osman. "İnşacı Bir Fikir ve Bilim Adamı Prof. Dr. Hasan Onat”. Türkiye Yeni Ufuklar Dergisi (Aralık 2020), 87-89.

Aydınlı, Osman. "Hasan Onat (1957-)”. Tanzimattan Günümüze Dinî ve Tasavvufî Düşünce Temsilcileri. ed. Süleyman Hayri Bolay. 6/4234-4246. Ankara: Nobel Yayınlar1, 2015.

Bağlığlu, Ahmet. "Prof. Dr. Ethem Ruhi Fığlalı Hocamız İle Prof. Dr. Hasan Onat Üzerine Söyleşi”. Türk Yurdu 399 (Kasım 2020), 97-102.

Donner, Fred M.. Muhammad and the Believers at the Origins of Islam. Cambridge Massachusetts and London: The Belknap Press of Harvard University Press, 2010.

Fığlalı, E. Ruhi. Günümüz İslam Mezhepleri. İzmir: İzmir İlahiyat Vakf1, 1. Bask1, 2008.

Hakyemez, Cemil. "Prof. Dr. Hasan Onat Hoca İle Öğrencilik Yıllarından Bir Kesit”. Türkiye Yeni Ufuklar Dergisi (Aralık 2020), 93-95.

Kalayc1, Mehmet. "Prof. Dr. Hasan Onat (1957-2020) Hocamizin Ardından...". Ankara Üniversitesi İlahiyat Fakültesi Dergisi 61:2(2020), 517-528.

Kamuoyuna Duyuru. Türk Yurdu 399 (Kasim 2020), 114-115.

Kırca, Celal. "Bir Gönül Dostu ve Bilim İnsan1: Prof. Dr. Hasan Onat". Türkiye Yeni Ufuk Dergisi (Aralık 2020), 83-86. 
Onat, Hasan(ed.). İslam Düşünce Ekolleri Tarihi. Ankara: Ankara Üniversitesi Uzaktan Eğitim Yayınları (Ankuzem), 1. Baskı, 2006.

Onat, Hasan vd. (ed.), İslam Mezhepleri Tarihi El Kitabı. Ankara: Grafiker Yayınları, 1. Bask1, 2012.

Onat, Hasan. İslam'a Yeni Yaklaşımlar. Eskişehir: Eskişehir Anadolu Üniversitesi Yayınlar1, 1. Bask1, 1999.

İslam Tarihi ve Medeniyeti, Ankara: Otto Yayınları, 1. Bask1, 2021.

İslamiyet-Hristiyanlık Kavramları Sözlüğü. Ankara: Ankara Üniversitesi Yayınları, 2013.

Maraş, İbrahim. "Hasan Onat'ın Tarikat ve Cemaatlere Yönelik Eleștirileri", Türk Yurdu 399 (Kasim 2020), 74-77.

Mektuplar (Hasan Onat'a Gönderilen Mektuplar): Hasan Onat Arşivi.

Nevbahtî ve Kummî, Şii Fırkalar, Çev. Hasan Onat ve dğr., Ankara: Ankara Okulu Yayınları, 2004.

Onat, Hasan. Emeviler Devri Şii Hareketleri. Ankara: Türkiye Diyanet Vakf1, 1. Bask1, 1993.

Onat, Hasan. Yirminci Asırda Şiilik ve Iran Devrimi. Ankara: Kamu Hizmetleri Araştırma Vakfi, 1. Bask1, 1996.

Onat, Hasan. Türkiye'de Din Anlayışında Değişim Süreci. Ankara: Ankara Okulu, 1. Bask1, 2003.

Onat, Hasan. İslam Ortak Paydası ve İslam Gerçeği. İstanbul: Endülüs Yayınevi, 2. Baskı, 2020.

Onat, Hasan. "İslam'da Asıl Olan Hayat ve Barıştır", Hürriyet (21 Temmuz 2014), 6.

Onat, Hasan. "Mezhep Kavramı ve Mezheplerin Doğuş Sebepleri”. Oş Ilahiyat Fakültesi Dergisi (2005), 7-23.

Onat, Hasan. "Yeni Bir İslam Medeniyetinin İnşası İçin Maturidi ve Maturidiliğin Önemi”, Prof. Dr. Hasan Onat. Erişim 03.06.2021.

http://www.hasanonat.net/index.php/107-yeni-bir-islammedeniyeti-icin-maturidi-ve-maturidiligin-oenemi

Onat, Hasan. "Değişim" Rüzgarları ve Yeniden Yapılanma”. Çankır'ya Hasret (Temmuz 1998), 1 ve 9.

Onat, Hasan. "Adalet Olmadan İnsanlık Olmaz". Akşam (23 Ağustos 2010), 17.

Onat, Hasan. "Adalet: Varoluşun Kurucu İlkesi”. Hürriyet (19 Temmuz 2013), 6.

Onat, Hasan. "Pankuş". Veryansın TV. Yayın Tarihi 27 Eylül 2020. 
https: / / www.youtube.com/watch?v=o7NqeIsjVao\&t=27s

Onat, Hasan. "Alevilik-Bektas,ilik (Din Ku"ltu"ru" Ahlak Bilgisi Dersleri ve Diyanet)". Alevilik Bektaşilik Türk Yurdu Yazıları. ed. Erdal Aksoy. 73-96. Tu'rk Yurdu Yayınlar1, 2019.

Onat, Hasan. "Bilgi, Bilim ve Yöntem”. Islam Bilimlerinde Yöntem. ed. Halis Albayrak.7-24. Ankara: Ankara Üniversitesi Uzaktan Eğitim Yayınları (Ankuzem), Ankara 2006.

Onat, Hasan. "Bir Üniversiteli Gencin Hatıra Defterinden Seçmeler". Hasan Onat'in Özel Arşivi, Ankara: 2021, 1-7.

Onat, Hasan. "Çăgdaş Eğitim ve Türkiye'nin Bazı Gerçekleri-Baş Yazı-”. Çankıri'ya Hasret (2 Eylül 1997), 1 ve 9.

Onat, Hasan. "Değişim Sürecinde Alevilik". Prof. Dr. Hasan Onat. Erișim 01.06.2021. http://www.hasanonat.net/index.php/99-degisimsuerecinde-alevilik

Onat, Hasan. "Demokrasi Kültürü ve Rejim Tartışmaları Üzerine-Baş Yaz1-". Çankıri'ya Hasret (2 Ağustos 1997), 1 ve 9.

Onat, Hasan. "Din Alanında Bilgi Kirliliği Üzerine". Akşam (21 Ağustos 2010), 14.

Onat, Hasan. "Din Alanında Doğru Bilgi Sahibi Olmanın Gerekliliği ve Din Kültürü ve Ahlâk Bilgisi Dersleri”. Eğitime Bakış 1/4 (Ekim, Kasım, Aralık 2005).

Onat, Hasan. "Din Alanında Eleştirel Yaklaşımın Önemi”. Akşam (31 Ağustos 2009), 16.

Onat, Hasan. "Din Alanında Yeniden Yapılanma Uzerine". Din Öğretiminde Yeni Yaklas,ımlar. ed. Mualla Selçuk. 97-107. Ankara: MEB Yayınları, 2000.

Onat, Hasan. "Din Eğitiminde İnsan Hakları ve Demokrasi", Ögretmen Adayları ve Öğretmenler Ic, in İnsan Hakları ve Demokrasi Eğitimi. ed. Refik Turan. 249-274. Ankara: Pegem Kitabevi, 2019.

Onat, Hasan. "Din İnsanı Özgürleştirir". Akşam (26 Ağustos 2009), 19.

Onat, Hasan. "Din İnsan İçin Vardır”. Akşam (15 Ağustos 2010), 18.

Onat, Hasan. "Din İstismarını Önlemenin Yolu Din Alanında Doğru Bilgiden Geçer". Akşam (13 Eylül 2009), 19.

Onat, Hasan. "Din Kimsenin Tekelinde Değildir". Akşam (16 Ağustos 2011), 15 . 
Onat, Hasan. "Din ve Siyaset Dilinin Korkudan Arındırılması Gerekir/Korku Yoğunluğu Sizi Korkutmuyor mu?”. Akşam (1 Eylül 2010), 17.

Onat, Hasan. "Dini Meseleleri Niçin Doğru Dürüst Tartışamıyoruz?”. Akşam (24 Ağustos 2011), 17.

Onat, Hasan. "Aklı Etkin Kullanmak/Düşünmek İbadettir", Hürriyet (12 Temmuz 2013), 6.

Onat, Hasan. "Dinî Yayınlarda Bilimsellik Sorunu (Çăgdaș ve İslâmî Bilimler Açısından)", Türkiye I. Dinî Yayınlar Kongresi (31 Ekim02 Kasım 2003). Ankara: Diyanet İşleri Başkanlığı Yayınları, 2004, 161-168.

Onat, Hasan. "Doğru/güzel Söz Sürekli Meyve Veren Ağaca Benzer". Prof. Dr. Hasan Onat. Erişim 01.06.2021. http://www.hasanonat.net/index.php/76-dogru-guezel-soezsuerekli-meyve-veren-agaca-benzer

Onat, Hasan. "Eğitim ve Özgürlük Üzerine". Diyanet Aylık Dergi 153 (Eylül 2003), 14-18.

Onat, Hasan. "Hayatın Anlamı İnsanın Yaratıc1 Yetilerinde Gizlidir/Başarmak Hayatın Anlamını Yakalamaktır”. Akşam (27 Ağustos 2011), 18.

Onat, Hasan. "Islam Bilimleri ve Yöntemi Açısından Tarihin Anlam ve Onemi. Kur an ve Islami İimlerin Anlaşılmasinda Tarihin Önemi. ed. M. Mahfuz Söylemez. 13-68. Ankara: Ankara Okulu Yayınlar1, 2013.

Onat, Hasan. "İlahiyat Fakültesinde Program Tartışmaları Üzerine", Türkiye'de Ilahiyat Fakültelerinin Konumu ve Dini Bilginin Niteliği, ed. Mahmut Ay vd. 309-318. Ankara: A.Ü. İlahiyat Fakültesi Yayınları, 2016.

Onat, Hasan. "İnsan Biricik ve Özgün Bir Varlıktır". Prof. Dr. Hasan Onat.

Erişim 02.06.2021.http://www.hasanonat.net/index.php/75-insanbiricik-ve-oezguen-bir-varl-kt-r

Onat, Hasan. “İnsan Onurunu Adalet Yüceltir”. Hürriyet (20 Temmuz 2013), 6.

Onat, Hasan. "İslam Ortak Paydası". Akşam (27 Temmuz 2012), 16.

Onat, Hasan. "İslam: İnsan Olma Projesi". Hürriyet (7 Temmuz 2014), 6.

Onat, Hasan. "İslâm'1 Anlamada Yöntem Sorunları". Gelenek ve Modernite Arasinda İslam Yorumlan. ed. Murat Akın vd.45-69. 
Konya: Necmettin Erbakan Üniversitesi Yayınları/İSAV Yayınlar1, 2018, 45-69.

Onat, Hasan. “İslam’ı Yeniden Düşünmek”, Akşam (11 Eylül 2009), 17.

Onat, Hasan. "Kadının Olmadığı Yerde Uygarlık Olmaz". Akşam (27 Ağustos 2010), 17.

Onat, Hasan. "Kur'an Anlaş1mak İçin İndirilmiştir". Akşam (12 Ağustos 2010), 17.

Onat, Hasan. "Medeniyet Yüksek İnsani Değerlerle İnşa Edilebilir". Akşam (15 Ağustos 2012), 16.

Onat, Hasan. "Mezhep Kavramı ve Mezheplerin Doğuş Sebepleri". Prof. Dr. Hasan Onat. Erişim 01.06.2021. http://www.hasanonat.net/index.php/98-mezhep-kavramve-mezheplerin-dogus-sebepleri

"Konuştuğu Zaman Yalan Söyler". Hürriyet (24 Temmuz 2014), 8.

Onat, Hasan. "Müslümanın Hedefi Zekat Verecek Hale Gelmektir". Akşam (3 Eylül 2010), 17.

Onat, Hasan. "Nic,in Din Egitimi?”, Türkiye'de Din Anlayışında Değişim Süreci. İstanbul: Endülüs Yayınevi, 2018 kitab1 içerisinde, 129-143.

Onat, Hasan. "Özgürlük ve Yaratıc1lı". Hürriyet (10 Temmuz 2013), 8.

Onat, Hasan. "Son Soluk". Hisar Aylik Fikir ve Sanat Dergisi 169 (Ocak 1978), 27.

Onat, Hasan. "Sosyal Değişme ve Aile- Baş Yaz1-", Çankıri'ya Hasret (2 Ekim 1997), 1 ve 9.

Onat, Hasan. "Türkiye'de Din Alanının Tartışmaya Açılması ve Önemi- Baş Yaz1-", Çankıri'ya Hasret (Ocak-Şubat 1998), 1 ve 9.

Onat, Hasan. "Türkiye'de Din Anlayışı". Prof. Dr. Hasan Onat. Erişim 01.06.2021. http://www.hasanonat.net/index.php/100tuerkiye-de-din-anlay-s

Onat, Hasan. "Türkiye'de Din ve Laiklik". Prof. Dr. Hasan Onat. Erişim 01.06.2021.

http://www.hasanonat.net/index.php/91-tuerkiye-de-din-ve-laiklik

Onat, Hasan. "Türkiye'de Zihniyet Sorunu - Baş Yaz1-", Çankıri'ya Hasret (2 Temmuz 1997), 1 ve 9.

Onat, Hasan. "Türkiye'nin Gerçekleri ve Din". Çankırı'ya Hasret (Kasım-Aralık 1997), 1 ve 9. 
Onat, Hasan. "Türkiye'nin İçine Sürüklendiği Gerilim Ortamı ve Din Olgusu- Baş Yazı-". Çankırı'ya Hasret (2 Haziran 1997), 1 ve 9.

Onat, Hasan. "Unuttuğumuz Bir Gerçek: Mü'minler Kardeştir”. Akşam (31 Ağustos 2010), 17.

Onat, Hasan. "Allah İnsandan İnsan Olmasını İster". Hürriyet (14 Temmuz 2014), 6.

Onat, Hasan. "Yeni Bir İslam Medeniyetinin İnşası İçin Maturidi ve Maturidiliğin Önemi”. Uluslararası Maturidilik Sempozyumu (Dünü, Bugünü ve Gelecegì). ed. So"nmez Kutlu. 677-701. Ankara: Ahmet Yesevi Üniversitesi Yayınları, 2018.

Onat, Hasan. "Yeni Bir İslam Medeniyetinin İnşası İçin Maturidi ve Maturidiliğin Önemi”. Prof. Dr. Hasan Onat. Erişim 03.06.2021.

http://www.hasanonat.net/index.php/107-yeni-bir-islammedeniyeti-icin-maturidi-ve-maturidiligin-oenemi

Onat, Hasan. "Çankırı'lı Olmak - Baş Yaz1-". Çankırı'ya Hasret (2 May1s 1997), 1 ve 9.

Onat, Hasan. Milli Eğitim Bakanlığı Tebliğler Dergisi. 63/2517 (Ekim 2000).

Onat, Hasan. Sorularla Mezhepler Tarihi. Ankara: 2016 (Yayınlanmamıs nüsha).

Onat, Hasan. Türkiye'de Din Anlayışında Değişim Süreci, İstanbul: Endülüs Yayınevi, 2. Baskı, 2018.

Onat, Hasan. "24 Y1ll1k Sessiz Yolculuktan Akılda Kalanlar", Prof. Dr. Hasan Onat. Erişim 07.06.2021.

http://www.hasanonat.net/index.php/64-24-y-11-k-sessizyolculuktan-ak-lda-kalanlar

et-Tusî, Nasirüddin, İmamet Risalesi, Ankara Üniversitesi Ilahiyat Fakültesi Dergisi, 1992, cilt: XXXII, 89-110.

Üçok, Nuran. "Nurten Onat Hanımefendi İle Eşi Hasan Onat Üzerine Söyleşi". Türk Yurdu 399 (Kasim 2020), 103-109.

Yozgat Lisesi arşivinde 728 numaralı Hasan Onat Dosyası. 


\section{SUMMARY}

Hasan Onat was born in the Eldivan district of Çankırı. He completed his primary education at Eldivan Center Primary School and at Yozgat High School as a boarding student. After a successful education, he enrolled in Theology Faculty of Ankara in 1974.

Hasan Onat acquired the habit of reading, researching and questioning a lot since his high school education; He began to write poetry and short stories. He kept diaries to see his intellectual development in Theology. He had some intellectual depressions during his high school and theology education. Beginning from high school, he had believed that a renaissance was needed in order to get rid of the problems that Muslims faced.

Hasan Onat's achievements in Theology, his spirit of inquisitiveness and his scientific curiosity kept Prof. Ethem Ruhi Fiğlalı's attention and he invited him to do a PhD in the History of Sects. He accepted this invitation and became a Research Assistant in Theology.

Hasan Onat, who started his doctorate in 1979, received the title of Doctor of Theology on 07.03.1986 with his thesis named "Shiite Movements in the Umayyad Period" under the supervision of E. Ruhi Fiğlalı. Then he was appointed to the staff of assistant professor. He worked as an Associate Professor and Professor. He gave undergraduate, graduate and doctorate courses in the fields of History of Islamic Sects, Contemporary Islamic Movements, Methodology of Social Sciences and other fields in his faculty for nearly forty years.

He has supervised more than fifty master's and doctoral theses. He tried to illuminate the first five centuries of Islamic thought with the theses he supervised. He has also signed many scientific studies. He published some of them, but he did not live to publish some of them. He has presented many papers to symposiums held at home and abroad.

Hasan Onat was awarded with "the Bravery of Science Award", due to his scientific achievements and bravely defending his views, in a ceremony held after the $2^{\text {nd }}$ Maturidi Yesevi Otağ 1 Congress held in Safranbolu on 31 August 2015-1-2 September 2015 by the Maturidi-Yesevi Otağı Scientific and Theological Research Association.

Hasan Onat, known with his honesty, kindness, courage and critical point of view, tried to understand, explain and endear Islam in his life. He thought and made thought through concepts and metaphors. He read, taught, discussed and shared. 
Hasan Onat has established a throne in the hearts of a wide audience thanks to his radio and television production and presenting for a quarter of a century. In the programs he produced, he tried to find solutions to the religious, social, political and cultural problems of the Turkish society, Muslims and humanity. As a newspaper columnist and social media user, he shared his ideas with social responsibility awareness.

Hasan Onat carried the ideas and methods of his predecessors forward and opened a new era in the field of History of Islamic Sects. He did a lot of research in his field, made translations, prepared textbooks and wrote columns for newspapers. He played an important role in the preparation of the Religious Culture and Moral Knowledge curriculum in primary and secondary education and in the renewal of theology programs.

Hasan Onat, who has always been in favor of innovation, worked to systematize a new scientific paradigm in Islamic sciences under the name of "Root Science Paradigm" and the thesis of "a new Islamic civilization" based on dignity, compassion and justice.

Hasan Onat gave very importance to Hanefi-Maturidi teaching for reconstruction of "a new Islamic civilization" and he explained his thesis as follows: "Hanefi-Maturidi's emphasis on the mind of thought can allow the development of critical thinking that is most needed today. The distinction between faith and deeds can prevent the operation of the tekfir mechanism so easily. We think that "equality in faith" can allow the perception of "chosenness" in an individual and community to be placed on a healthy footing, which facilitates religious abuse. What we are trying to say is that HanefilikMaturidism should not forget the fact that there are human manifestations only about the forms of understanding of Islam. Whatever its name, all sects are human formations that emerged after the death of the Prophet; no sect can be identified with Islam. Every denomination has its wrongs besides the truth. When we understand the denominations well, we understand that differences are wealth and that the past must be understood correctly in order to get rid of the mortgage of the past."

Hasan Onat, who devoted his life to science, was just beginning to reap the fruits of his work, but he caught the Covid-19 disease and died on 26.09.2020. 